NBER WORKING PAPER SERIES

\title{
DRESSED FOR SUCCESS? THE EFFECT OF SCHOOL UNIFORMS ON STUDENT ACHIEVEMENT AND BEHAVIOR
}

\author{
Elisabetta Gentile \\ Scott A. Imberman \\ Working Paper 17337 \\ http://www.nber.org/papers/w17337
NATIONAL BUREAU OF ECONOMIC RESEARCH
1050 Massachusetts Avenue
Cambridge, MA 02138 \\ August 2011
}

We gratefully acknowledge funding and support from the American Education Finance Association New Scholars Award. We also thank Aimee Chin, Steven Craig, Julie Berry Cullen, Chinhui Juhn, Melinda Sandler Morrill, Stuart Rosenthal, two anonymous referees and seminar and conference participants at the Institute for Research on Poverty Summer Research Workshop, University of California - San Diego, University of Texas at Dallas, University of Houston Center for Public Policy, Texas Camp Econometrics, as well as the American Education Finance Association and Southern Economic Association annual meetings. Finally, we thank Mykhailo Sitiuk for excellent research assistance. The views expressed herein are those of the authors and do not necessarily reflect the views of the National Bureau of Economic Research.,

NBER working papers are circulated for discussion and comment purposes. They have not been peerreviewed or been subject to the review by the NBER Board of Directors that accompanies official NBER publications.

(C) 2011 by Elisabetta Gentile and Scott A. Imberman. All rights reserved. Short sections of text, not to exceed two paragraphs, may be quoted without explicit permission provided that full credit, including (C) notice, is given to the source. 
Dressed for Success? The Effect of School Uniforms on Student Achievement and Behavior Elisabetta Gentile and Scott A. Imberman

NBER Working Paper No. 17337

August 2011

JEL No. I21

\begin{abstract}
$\underline{\text { ABSTRACT }}$
Uniform use in public schools is rising, but we know little about how they affect students. Using a unique dataset from a large urban school district in the southwest United States, we assess how uniforms affect behavior, achievement and other outcomes. Each school in the district determines adoption independently, providing variation over schools and time. By including student and school fixed-effects we find evidence that uniform adoption improves attendance in secondary grades, while in elementary schools they generate large increases in teacher retention.
\end{abstract}

Elisabetta Gentile

8 QYHUWWIRI RXWRQ

204 McElhinney Hall

Houston, TX 77204-5019

egentile@mail.uh.edu

Scott A. Imberman

Department of Economics

University of Houston

204 McElhinney Hall

Houston, TX 77204

and NBER

simberman@uh.edu

An online appendix is available at:

http://www.nber.org/data-appendix/w17337 


\section{Introduction}

In 1996, the US Department of Education found that only $3 \%$ of public schools required uniforms. As a result of this and in the belief that uniforms make "schoolrooms more orderly [and] more disciplined," President Clinton and the Department of Education encouraged schools to adopt uniforms (Mitchell, 1996). This led to substantial growth in the use of uniforms in public schools. By 2005 uniform adoption had more than quadrupled as it spread to $14 \%$ of public schools. ${ }^{2}$ Today, many large school districts have some schools that require students to wear uniforms. Most notably Philadelphia public schools require all students to wear uniforms while New York City, Long Beach, and Dallas require uniforms in pre-secondary grades. Other large school districts, including Miami-Dade, Houston, Chicago, and Boston, permit individual schools to adopt uniforms.

Despite their widespread use and even though politicians and administrators specifically cite improvements in discipline and achievement as justifications for uniform adoption (Archibold, 1998; Los Angeles Daily News, 2009; Steinberg, 1998), the effects of uniforms on students remain unclear. In addition, proponents of uniforms suggest that the largest impacts may be on non-cognitive skills such as self esteem and discipline. Recently researchers have established that non-cognitive skill formation is an important part of education and may be just as important a determinant of students' future social and employment success as academic ability (Heckman and Rubinstein, 2001; Heckman, Stixrud and Urzua, 2006; Imberman, 2011; Jacob, 2002; Segal, 2009).

In this paper, we identify the impact of uniforms on student achievement, attendance and behavior using student-level panel data from a large urban school district in the southwest United States (LUSD-SW). Since schools in LUSD are free to set their own uniform policies and most schools adopt uniforms during the time period for which we have data, we are able to produce causal estimates of uniform impacts on student outcomes through the use of school, student and principal fixed-effects.

\footnotetext{
${ }^{2}$ US Department of Education, National Center for Education Statistics
} 
Theoretically it is unclear how uniforms might affect students' achievement and behavior. Uniforms could improve student outcomes through a few mechanisms. First, they potentially provide direct improvements in safety by making it easy to identify unauthorized visitors to a school, preventing the use of gang colors and insignia, and reducing theft since students no longer bring expensive clothing items to school (Stanley, 1996). For example, the Los Angeles Times argues that "in gang-plagued areas where wearing a certain color is enough to set off a fight, [uniforms] create a more neutral atmosphere on campus" (Los Angeles Times, 2009). Second,uniforms may instill respect for authority in students which, in turn, could improve behavior and reduce classroom disruptions. Third, a concern for adolescents, particularly girls, is that there may be substantial peer pressure to dress well which could, in turn, lead to low self esteem if a child is unable to dress "properly" due to low income or parental preferences. Uniforms negate much of this peer pressure by requiring students to wear the same clothing.

Uniforms also make the process of dressing for school faster, particularly for adolescent girls, potentially providing extra time for sleeping or studying. For example, at a high school near Boston a senior remarks that "for some people it takes hours to get dressed. If we had a uniform it would take three minutes" (Alspach, 2007). Finally, uniforms provide an additional tool that administrators and teachers can use for discipline by providing students with rewards of "uniform-free" days for good behavior.

Nonetheless, uniforms could negatively affect student outcomes. One possibility is that the restrictiveness of uniforms induces students to become disruptive as a way to rebel against authority or increased conformity could make school boring. Another possibility is that improvements generated by uniforms could induce students with behavioral problems who would otherwise have attended alternative education environments such as charter schools or dropped out of school to remain in the public school. This could ultimately reverse improvements from uniforms via negative peer effects (Carrell and Hoekstra, 2010; Gaviria and Raphel, 2001; Figlio, 2007; Imberman, Kugler and Sacerdote, forthcoming). On the 
other hand, such an impetus to remain in the public schools could also occur for high quality students, and thus uniforms could generate a positive peer-effect in the long-run. Finally, some research has suggested that uniforms may actually reduce self-esteem as it restricts the ability of students to express themselves (Wade and Stafford, 2003).

There are also considerations beyond student behavior and achievement when schools decide whether to adopt uniforms. In particular, opponents argue that uniforms restrict students' rights and impose financial hardships (Brunsma and Rockquemore, 1998). For example, a recent report in Britain found that uniform costs varied by a factor of 10 and climbed as high as $£ 200$ (BBC, 2003). While most schools with uniform policies in the US provide subsidies to low-income families, the remaining share of costs may still be substantial.

Despite the large growth in the use of uniforms in public schools over the past decade, there is very little empirical research that assesses their impacts on student outcomes. Brunsma and Rockquemore (1998) compare students who attend schools with and without uniforms in a nationally representative sample of high-school students. They find little difference in absenteeism, behavior problems, and substance abuse while uniforms correlate negatively with test scores.$^{3}$ Brunsma (2004) and Yeung (2009) conduct further analyses using similar data and find no significant impact on behavior or achievement. Stanley (1996) finds, on the other hand, that after Long Beach instituted uniforms behavior improved $4^{4}$

A potential drawback with these studies is that they rely on cross sectional variation in uniform status $5^{5}$ The exception is Stanley (1996) who compares results before and after adoption, but in this case she is limited to a district-wide change which might be contempo-

\footnotetext{
${ }^{3}$ Bodine (2003) notes that their sample of schools that require uniforms are almost all private schools and hence the results may not apply to public schools.

${ }^{4}$ A related paper is Evans, Kremer, and Ngatia (2008) who evaluate a random lottery that gave uniforms to students in Kenya. They find improvements in attendance and, preliminarily, test scores for students who receive uniforms. However, while this suggests that uniforms can be effective tools at improving student outcomes, the context is very different from the United States. In this case the authors do not evaluate a policy change of imposing uniforms, rather they measure the impact of providing uniforms for free to students in schools where they are already required. This reduces the cost of education for those students, who would have had to purchase the uniforms otherwise. Thus, they are not able to evaluate the effect of a change in uniform policy.

${ }^{5}$ Yeung improves on the regression models by focusing on value-added scores rather than test-score levels.
} 
raneous with general trends in behavior. Hence, the estimates are subject to bias as schools and districts that choose to adopt uniforms may be inherently different from those that do not. Of particular concern is that schools and districts that adopt uniforms are likely to have lower achievement and more behavior problems than those that choose not to adopt uniforms. In addition, students and parents may choose schools in part based on whether or not they have uniforms. Alternatively, if uniforms have an impact on student outcomes parents may respond to this by changing schools. For example, parents may treat uniforms as a signal by administrators that they are working to improve a school. In this case, parents who are more concerned about their children's education would be inclined to switch to schools with uniforms. Since parental concern is correlated with student outcomes, estimates that do not account for this would be biased. While controlling for school and student characteristics helps address these biases, they are very likely to be insufficient as there are many aspects of a school's decision to adopt uniforms, such as principals' preferences for discipline and the quality of teachers, and parents' decisions to send their children to uniformed schools that affect student outcomes and are inherently unobservable.

The sparseness and identification difficulties of the prior literature provide an unclear picture of how uniforms affect student outcomes. To fill this gap in the literature, we address the selection problem by exploiting the panel nature of our data. As such, we include student and school fixed-effects in our models. These account for unobservable characteristics of students and schools themselves that are correlated with uniform status and fixed over time. We also provide models that further control for principal fixed-effects. These help account for uniform adoption that is correlated with the disciplinary preferences of school leaders. Using this strategy we are able to provide, to our knowledge, the first causal estimates of the impact of uniforms on achievement, attendance, behavior, retention and school switching. We also investigate whether uniforms affect teacher attrition, which has become increasingly problematic in urban schools..$^{6}$

\footnotetext{
${ }^{6}$ See e.g. Boyd, Lankford Loeb, Ronfeldt and Wyckoff (2010); Clotfelter, Glennie, Ladd and Vidgor (2008); Feng (2010); Rivkin, Hanushek and Kain (2005); and Watlington, Shockley, Guglielmino, and Felsher
} 
In contrast to most of the prior literature we find that uniforms generate improvements in attendance in middle and high/school. The attendance results are particularly strong for girls. We also find that uniforms significantly reduce teacher attrition in elementary schools. Nonetheless, uniforms have little impact otherwise. We find no statistically significant effect on disciplinary infractions, achievement, grade retention or student movements between schools. Hence, overall we conclude that the effects of uniforms are minimal with the exceptions of attendance for middle and high-school students and teacher attrition in elementary schools. Although we cannot completely rule out that other contemporaneous policy enactments generate the attendance and teacher attrition effects rather than uniforms, the robustness of our estimates to the inclusion of principal fixed-effects, the finding that our estimates are similar when we account for adoption under new principals, and the lack of any increase in disciplinary infractions even in the short term suggest that the results are unlikely to be due to concurrent changes in enforcement policies.

\section{Uniforms in LUSD-SW}

LUSD is an urban school district with more than 200,000 students and close to 300 schools, making it one of the largest in the country. The district has substantial poverty - $59 \%$ of students qualified for free or reduced-price lunch in 2006-07. Like other urban school districts it is also heavily minority - $59 \%$ of students are Hispanic and $29 \%$ are African-American. Parents of students in LUSD have a number of choice options which could allow students to move in response to uniform policies. First, LUSD itself has a large magnet program. Second, the LUSD area has a substantial number of charter schools and private schools. In 2004-05 state charter schools near to or within LUSD's boundaries had a population equal to $9 \%$ of LUSD's enrollment. LUSD is also surrounded by many suburban school districts:7 Given these characteristics of the district, we will consider how uniforms affect student movements (2010).

${ }^{7}$ Eleven districts directly border LUSD. 
in addition to test scores, attendance, retention and behavior.

LUSD has permitted its schools to require students to wear uniforms since at least $19928^{8}$ Initially, only a handful of schools required uniforms. However, uniform adoption grew substantially over the following 13 years. Of schools that responded to our survey of uniform policies, which we describe in more detail below, only $10 \%$ required uniforms in 1993. By $2006,82 \%$ of these schools required uniforms. In addition, no schools abandoned uniforms after adoption. These characteristics suggest that parents and school administrators in LUSD generally believe that uniforms are helpful.

Schools are given wide latitude by LUSD in designing their uniform policies. Nonetheless, while certain characteristics of school uniforms vary across schools, such as color choices and whether a specific shirt purchased from the school is required, the policies are very similar. As of the 2007-08 school year, all schools that require uniforms mandate specific colors and styles for both shirts and pants. Almost all of these schools specify between 1 and 3 colors for shirts, and casual or denim pants in khaki or navy colors. Some schools specifically limit students to wearing polo style shirts. Only a handful of schools require students to purchase specific shirts with a school logo. Some middle and high schools also require different grades to wear assigned colors. The most common uniform includes a polo style shirt in one of the school's colors combined with khaki, denim, or navy pants. Girls are generally given the option of wearing pants or skirts.9

\footnotetext{
${ }^{8}$ The earliest any school required uniforms was in 1968, but this was a school operating under contract with LUSD rather than being directly run by LUSD. Of LUSD's own schools, the earliest date provided in our survey of uniform policies was 1992.

${ }^{9}$ Disobeying a mandatory uniform policy is considered a "level II" disciplinary infraction, which requires intervention by a school administrator. Such a violation can result in a variety of punishments depending on the severity of the infraction and the student's prior behavior. These can range from a call to the student's parent to in-school suspension, although the administrator is given discretion to increase or reduce the punishment beyond this range if necessary. Repeated violations can result in out-of-school suspension or placement in a disciplinary alternative education center.
} 


\section{$3 \quad$ Empirical Strategy}

The primary concern with an analysis of the effects of school uniforms on student outcomes is that schools and districts choose whether or not to adopt uniforms. As a result uniform adoption is likely correlated with unobservable characteristics of the school that could affect student performance, such as neighborhood characteristics or parental involvement in the school. If this is the case, then naïve OLS estimates will be biased. The selection process is further complicated by the possibility that schools adopt uniforms in response to existing achievement and behavior levels or even trends in student outcomes. For example, schools may decide to adopt uniforms in response to increasing discipline problems. In addition, parents and students may respond to uniform policies by changing schools.

We can model this framework as

$$
Y_{i j t}=\alpha+\beta U \text { niform } \text { fort }+\mathbf{X}_{\mathbf{i j t}} \boldsymbol{\Omega}+\gamma_{\mathbf{i}}+\delta_{\mathbf{j}}+\epsilon_{\mathbf{i j t}} .
$$

where $Y_{i j t}$ is an outcome for student $i$ in school $j$ and academic year $t$, Uniform is an indicator for whether or not the student has to wear a uniform, $\mathbf{X}$ is a set of student characteristics and grade-by-year fixed-effects. While we use this model to measure behavioral impacts such as attendance and discipline as well as grade retention and school switching, as is standard in education production models we look at the impact on changes in achievement via a restricted value-added model. Hence for achievement models the dependent variable is $Y_{i j t}-Y_{i j, t-1} \cdot \gamma, \delta$ and $\epsilon$ are error terms where $\gamma$ varies over students but not schools or time, $\delta$ varies over schools but not students or time, and $\epsilon$ varies over schools, students and time. Ideally we would want Uniform to be uncorrelated with $\gamma, \delta$, and $\epsilon$, but due to the reasons described above this is unlikely. Table 1 provides some evidence for this. Using the first year of our data, 1993, we provide characteristics of schools by whether they never adopt uniforms, are early adopters, or are late adopters of uniforms. While schools that adopt late are generally similar to those that adopt early, schools that never adopt uniforms have 
statistically significantly higher achievement, lower free lunch eligibility rates, and smaller minority populations.

Thus, a simple regression that compares schools with uniforms to those without uniforms will likely be biased. The availability of panel data where schools adopt uniforms at different times and students move between schools with and without uniforms allows us to use student and school fixed-effects to address this concern. This procedure accounts for any unobserved characteristics of students and schools that may affect the school's decision to adopt uniforms, the parents' decision to move their child to a school with uniforms, and student outcomes, as long as these characteristics do not vary over time. Thus, we correct for omitted variables such as parents' preferences for discipline, students' innate tendencies to misbehave, student ability, and schools' long-term problems with discipline and test scores.

Hence, in our model bias remains only if students select into uniformed schools or schools adopt uniforms based on time-varying characteristics. To test the validity of this strategy, we will provide event-study analyses that track student outcomes in each year before and after uniform adoption, so that we might identify if there is any evidence of additional trending after controlling for the fixed-effects. Since uniforms may have different impacts by gender and grade level, we conduct all of our analyses separately for males and females and for elementary (grades 1 - 5) and middle/high school (6 - 12) grades as well as providing pooled estimates. Further, we estimate variations on the model in equation (1) to look at different effects by student race, economic status and achievement. In addition, we test whether uniform effects vary by student characteristics given the student is in a school with other students like him or her - i.e. does the effect on black students in a heavily black school differ from black students in a heavily white and Hispanic school?.

A second concern is that uniform adoption by a school may be part of a wider policy change. Of particular concern is that uniforms may be implemented concurrently with changes in discipline enforcement. To the extent that this is true, then our estimates represent the reduced-form impact of such a policy combined with uniform adoption. Unfortu- 
nately there is no way to test for this directly, since enforcement enhancements - as well as other policy changes - are unobservable.

While we cannot fully rule out that our estimates pick up the effects of other policies that are adopted contemporaneously with uniforms, we nonetheless provide some analyses that assess the extent to which changes in policy may be affecting our estimates. First, we conduct regressions that include principal fixed-effects. This addresses the possibility that principals who are strict disciplinarians may be more inclined to adopt uniforms or when certain principals consistently institute a set of policies combined with uniforms in different schools. Results using this model are similar to our baseline estimates. Our second test is to interact uniform status with whether a school's uniform is adopted during the first two years of a principal's term. This addresses the possibility that some schools respond to worsening behavior by bringing in a new principal who includes uniforms as part of a package of reforms. In addition, new principals may be more willing to experiment with different strategies, including uniforms. If these phenomena were driving our estimates we would expect to see statistically significantly different impacts for uniforms adopted early in a principal's term relative to later. While we do find that new principals who adopt uniforms have higher infraction rates than old principals, there is no statistically significant difference in achievement gains or attendance. Finally, and perhaps most importantly, when we break down infractions into those resulting in an in-school suspension and those resulting in an out-of-school suspension, we find no significant impact on either type of punishment. Nor do we find statistically significant changes in the rates of in-school suspensions relative to more severe infractions in school-level regressions. If administrators increased enforcement concurrent with uniform adoption, we would expect to see more incidences of disciplinary infractions, at least temporarily. Hence, while we cannot rule out the possibility that enforcement plays a role in our results, these tests suggest that such a story is unlikely. 


\section{Data}

In this paper we utilize two sources of data from a large urban school district in the southwest United States (LUSD-SW). The first is a set of administrative records for students in LUSD from 1993 through 2006 10 This data includes student demographics, test scores, disciplinary records and attendance records for every student in LUSD. Testing data include students's scaled scores on the Stanford Achievement Test $\left(9^{\text {th }} \& 10^{\text {th }}\right.$ editions) which we standardize within grade and year 111 The Stanford Achievement Test is a nationally normed standardized exam that LUSD administers annually in grades 1 through 11 . The exams are "low stakes" in the sense that they do not count towards state accountability requirements or requirements of the Federal "No Child Left Behind" Act. However, students do need to achieve minimum scores on the reading and math portions to advance to the next grade. Discipline data includes any infraction that results in an in-school suspension or more severe punishment. Attendance records include the attendance rate for each student. Test score data is only available starting in 1998-99, hence while we use all years for estimates of the impacts on attendance, discipline, grade retention, school switching and the likelihood of leaving LUSD, we must restrict our analysis to 1998-99 and later for test score analyses.

Unfortunately, LUSD does not keep centralized records of when schools adopted uniforms. Thus, we emailed and mailed a survey to the principal of each school in LUSD with the following questions in the fall of 2007 :

- Does your school currently require students to wear uniforms? Note that we define a uniform as any outfit where a particular style of shirt (i.e. polo) and bottom (i.e. khaki, skirt, etc.) and a specified color are required.

\footnotetext{
${ }^{10}$ Since the data used in this study are confidential, researchers interested in replication studies or access to the data for other reasons should contact the authors to be informed of the district identity. In order to access the data the researchers will be required to submit a research proposal to LUSD's research office. Upon receiving written approval from LUSD we will provide the data directly to the requestors.

${ }^{11}$ In 2005-06 and 2006-07 LUSD received some evacuees from Hurricanes Katrina and Rita. While we keep these students in the data, they do not contribute to the standardization. Results dropping evacuees are nearly identical.
} 
- If your school currently requires uniforms, what school year did you first require them? Were there any years since then when the requirement was suspended?

- If your school currently does not require uniforms, did you ever require them in the past, and if so, could you please provide the years during which students were required to wear uniforms?

We then followed up via telephone with any school that did not respond to the initial survey or to clarify their answers. If the principal did not know the date we requested that he or she ask his or her staff members. Data collection was completed in October, 2008 $\sqrt{12}$ For the 292 schools that were in operation in the $2007-08$ school year $79 \%$ were able to provide dates of uniform adoption while the date could not be determined for $14 \%$ and $7 \%$ of the schools refused to participate in the survey ${ }^{13}$ Figure 1 shows the number of schools in LUSD that require uniforms, do not require uniforms, or for which the uniform requirements could not be determined. Since our survey was based off of schools existing in 2007-08 earlier years have higher rates of unknown uniform status than later years. Nonetheless, it is clear that number of schools requiring uniforms increased substantially over the course of the sample. Since we use school fixed-effects to help identify the uniform impact it is also important to know how many schools switch to requiring uniforms over the course of the sample. From 1993-04 to 2006-07 166 schools adopt uniforms. From 1999-00 through 2006-07, the period after the first year of testing data, 84 schools adopt uniforms. Hence there is substantial variation in policies during the period for which we have data. ${ }^{14}$

\footnotetext{
${ }^{12}$ In some cases we were provided a range of years or a statement that uniforms had been required since a certain date. In these cases if the dates provided were after the start of our sample period we followed up and requested that the principal ask other staff and faculty to identify specific dates of adoption. If an exact date still could not be determined we dropped that school from our sample.

${ }^{13}$ Some schools responded that the uniform policy was adopted before a certain date. In these cases, unless that date was prior to the start of our data in 1993, we considered the uniform adoption date for those schools to be unknown. This occurs for 13 schools. In addition three schools stated that they recommended but did not require uniforms. These schools are considered to not have a uniform for the purposes of this study since there would be no punishment for the student if they choose not to wear the uniform.

${ }^{14}$ The LUSD data also includes 39 charter schools directly authorized by LUSD. However, while large in numbers they make up a small portion of the observations $(2.4 \%)$ and only 8 changed uniform policies during the time-span of our data. Hence, due to the school fixed-effects very few charters contribute to the identification. Indeed, results that exclude charter schools are very similar to our main results.
} 
Table 2 provides summary statistics for students by their school's uniform status split by grade level. In general, uniform and non-uniform schools have similar demographics, the exceptions being that students in middle/high grades who attend uniform schools are poorer, students in uniformed elementary schools are more likely to be at-risk, and students in both elementary and middle/high schools with uniforms are more likely to be Hispanic.15 In terms of outcomes, test scores are higher in elementary non-uniform schools than in uniform schools, albeit generally not significantly so, while for both grade levels uniform schools have more disciplinary infractions and higher attendacne rates.

In general the schools for which we could not determine uniform policies are demographically similar to the rest of the schools in LUSD, although elementary schools have more minority and low-income students. On the other hand, the unknown schools have consistently lower test scores than schools where uniform status is known. This leads to a concern that our results may be biased due to survey non-response. The school fixed-effects mitigate this concern as they limit the bias to non-response based on time-varying characteristics of schools. Nonetheless, some bias may remain. To address this we conduct inverse-probability weighted regressions where observations are weighted by the inverse of the predicted values from a propensity score of the likelihood of a school being included in the sample ${ }^{16}$ Estimates using this procedure are very similar to our main estimates ${ }^{17}$ Hence, it appears unlikely that our results are affected by non-response bias.

\footnotetext{
${ }^{15} \mathrm{~A}$ student is considered at-risk if he or she is low-achieving, has previously been retained, is pregnant or a parent, is LEP, has been placed in alternative education or juvenile detention, is on parole or probation, is homeless, or has previously dropped out of school.

${ }^{16}$ We estimate a probit of being in the sample from the universe of schools in LUSD from 1993 through 2006. Data is from the state education agency. We include year dummies; per-student total and instructional expenditures; enrollment shares by race, economic disadvantage, limited-English proficiency, vocational program, special education, bilingual education, gifted, grade level, and mobility; teacher experience, baseline salaries, tenure, and specialization; and student-teacher ratios in the regressions. See Wooldridge (2002, pp. 587-590) for a technical treatment.

${ }^{17}$ Results provided in Online Appendix Table 1. The online appendix can be found at http://class.uh.edu/faculty/simberman.
} 


\section{Results}

\subsection{Determinants of Uniform Adoption}

Before analyzing the impacts of uniforms, it is useful to understand why schools in LUSD choose to adopt uniforms. In Table 3 we provide estimates from probit regressions of the likelihood of adopting uniforms on mean student characteristics in a school the prior year. In addition to the variables listed in the table, the regressions include year indicators and controls for the share of the students in each grade level. To avoid contaminating these estimates with changes induced by uniforms we exclude all school-years after uniform adoption. These results paint a nuanced picture of the determinants of adoption depending on whether the school is elementary or secondary. First, elementary schools appear to adopt when they are gaining more students but with less spending per student. One possible explanation is these schools use uniforms as a way to maintain control in the school when there are fewer resources available for behavior monitoring. Peculiarly, however, student-teacher ratios fall prior to adoption. The share of students who have special needs also falls. For secondary schools, the results provide a clearer picture. The schools adopt uniforms when there is an increase in low-income non-minority students. Adoption is also associated with having more at-risk and special education students.

\subsection{Impacts on Discipline and Attendance}

Since uniform proponents often cite behavioral improvements as the main benefit of uniforms, we start by considering the impact of uniforms on disciplinary infractions and attendance. Table 4 provides our primary estimates of these outcomes for elementary and secondary students, respectively. Columns (1) and (3) include school and student fixed-effects along with controls for students' economic status and grade-year fixed-effects. Columns (2) and (4) provide estimates where we add principal fixed-effects. ${ }^{18}$

\footnotetext{
${ }^{18}$ LUSD principals undergo a substantial amount of churn as $14 \%$ of schools in LUSD get a new principal each year. This common movement of principals between schools is useful for this analysis as it ensures a
} 
For elementary students we find little evidence of uniforms having impacts on attendance or disciplinary infractions 19 On the other hand, for middle and high school students, we find significant improvements in attendance rates, particularly for females. School fixedeffects estimates in column (3) indicate that female attendance increases by a statistically significant 0.3 percentage points after uniform adoption. This is equivalent to an additional $\frac{1}{2}$ day of school per year in a 180 day school-year. For males the point estimate is $0.2 \mathrm{pp}$ but it is not statistically significant. However, in column (4), when we add the principal fixed-effects the estimates get larger with female and male impact estimates rising to 0.5 and $0.4 \mathrm{pp}$, respectively. These estimates are statistically significant for both genders. For disciplinary infractions estimates for middle/high school students are similar to those for elementary students ${ }^{20}$

As mentioned above, a concern with these estimates is that they may be due to uniforms being adopted concurrently with an increase in discipline enforcement and other policy changes. If this is the case then we may be misidentifying the uniform impact as a more general impact of school reform. In addition to the robustness of our results to principal fixed-effects, another piece of evidence against this concern is the lack of significant impacts on disciplinary infractions. If uniforms are adopted along with an enhanced enforcement policy we would expect to see an increase in infractions. However, a null finding for overall discipline may hide shifts in the types of punishment. In particular, we might expect enhanced enforcement to lead to a shift towards more severe punishments. To test this, in Table 5 we provide impact estimates of the number of in-school suspensions, the lowest level of infraction in our data, or out-of-school suspensions a student receives ${ }^{21}$ If there is

substantial amount of variation remains even after controlling for both principal and school fixed-effects. We also found that results were similar to baseline if instead of principal fixed-effects we used principal-school spell fixed-effects in place of school fixed-effects.

${ }^{19}$ Online Appendix Table 2A provides counts for each of the fixed-effects in these models.

${ }^{20}$ Estimates for discipline and attendance using gains models are qualitatively similar with the exception of a significant negative effect for elementary male attendance. These results are provided in Online Appendix Table 3.

${ }^{21}$ Infractions broken down by type was not collected in 1995-96 and 1996-97. In-school and out-of-school suspensions account for $96 \%$ of recorded infractions. The rest are expulsions and referrals to alternative disciplinary schools. 
an increase in enforcement we would expect to see a shift from less severe to more severe punishments. The results in Table 5 provide little evidence for a shift in punishments as only one estimate is statistically significant at the $10 \%$ level and this becomes insignificant when principal fixed-effects are added. Further, in Online Appendix Table 4 we estimates school-level regressions of uniform status on infraction, in-school suspension, out-of-school suspension and other infraction rates. We also estimate the impact of uniforms on the percent of infractions in a school resulting in an in-school suspension. Only one estimate, in-school suspension rates in middle/high schools, is statistically significant and only at the $10 \%$ level. Finally, in Online Appendix Table 5 we conduct another test where we interact uniform status whether the school adopts uniforms during the first two years of a principal's term. New principals in particular may be more likely to adopt uniforms as a part of a broader package of school reform, hence we need to see whether our results hold while accounting for these principals. ${ }^{22}$ While we find that when uniforms are adopted under new principals there is a significant increase in infractions, this appears to have little impact on the overall estimates as the main effects (e.g. the uniform impact for existing principals) are similar to the baseline estimates for both attendance and discipline.

Another potential concern is that schools may adopt uniforms when experiencing trends in attendance and discipline. The latter is of particular concern since schools might be inclined to adopt uniforms in response to changes in discipline. To address this, we estimate a variation of equation 1 where instead of using an indicator variable for whether a school requires a uniform, we use indicators for a school being in a period 6 or more, 5, 4, 3, or 2 years prior to uniform adoption. In addition, so that we might track the evolution of uniform effects after adoption, we include indicators for the school being in the year of adoption, and $1,2,3,4$ and 5 or more years after. Note that we omit one year prior to adoption so that trends can be detected as significant deviations from that year's estimate. The overall impact of being a school that adopts uniforms at some time in the data is captured by the

\footnotetext{
${ }^{22}$ These models have school and student fixed-effects but no principal fixed-effects.
} 
school fixed-effects. These models do not include principal fixed-effects. The results from these event study analyses are provided in Figures 2 and 3 where the solid line shows the coefficient estimates and the dotted lines show $95 \%$ confidence intervals. ${ }^{23}$

Figure 2 provides the event studies for attendance rates. For both elementary and middle/high schools the graphs show little evidence of pre-adoption trending. Further, we see clear increases in attendance rates after adoption for middle/high students, although for each given year they are not statistically significant. Nonetheless, the graph suggests that the the significant pooled estimates provided in Table 4 are a level shift in attendance rates, rather than a trend shift.

For disciplinary infractions, we see in Figure 3 that while there is an increase up to four years prior to adoption for elementary schools, this flattens out afterwards indicating no significant trending in the four years before adoption. For middle and high schools, the infraction rates are flat throughout the period prior to adoption. After adoption, the figures show no significant impact on infractions at any time for both grade levels. We also provide event study figures for in-school and out of school suspensions. For elementary students the pattern for out-of-school suspensions is similar to the overall pattern, while for in-school suspensions there is no evidence of pre-trends and a slight but only marginally significant uptick in later years. For middle and high school students both in-school and out-of school suspensions show similar patterns to overall infractions in the years after adoption, but outof-school suspensions experience a small increasing trend prior to adoption. This suggests that our baseline estimates may slightly understate the reduction in out-of-school suspensions from uniforms.

In Table 6 we investigate whether the impacts (or lack thereof) on attendance and discipline vary by a student's race or racial composition of a school and find mixed results. ${ }^{24}$ For elementary schools, African-Americans and Hispanics respond most positively in terms

\footnotetext{
${ }^{23}$ Coefficients and standard errors are provided in Online Appendix Tables 6 - 7.

${ }^{24}$ The left-out category includes whites, asians, and Native Americans. Although we would normally consider the latter two categories to be separate minorities, their sample sizes are too small to get precise estimates at $2.9 \%$ and $0.1 \%$, respectively. Whites account for $10.2 \%$ of the sample.
} 
of attendance, particularly African-American students in schools with a higher than average (in the district) AA population. Nonetheless, when added to the main effects, these do not differ on net from zero and in fact, the estimates suggest that students from other races are negatively impacted by uniforms. On the other hand, AA students experience increases in disciplinary infractions not experienced by other races.

For middle/high students while there are no significant differences in discipline effects, the attendance results differ sharply from those for elementary students. The results suggest that most of the improvements in attendance accrue to students in schools that are below median in their African-American or Hispanic populations, regardless of race. Hence uniforms appear to be more effective in mixed-race or primarily Caucasian and Asian (the other two major racial populations in LUSD) schools. The exception to this pattern is that AA students in schools with high AA populations also experience improvements in attendance.

In the Online Appendix we provide a number of additional specification and heterogeneity tests. Online Appendix Table 8 provides results when we drop schools that adopt uniforms early (before 1994) or late (after 2004) and find qualitatively similar results. Similarly for Appendix Table 9 where we limit the sample to students who take math, reading and language achievement exams, although in this case we get a marginally significant increase in middle/high discipline infractions. In Appendix Table 10 we split the elementary estimates by grades 1 - 3 and grades $4-5$ while middle/high estimates are split by grades 6 - 8 and 9 - 12. The results are similar to baseline. In Appendix Table 11 we provide models for heterogeneity by economic disadvantaged status similar to those provided in Table 6 for race. The results suggest that the attendance improvements mainly accrue to students who are economically disadvantaged, particularly those who are in high poverty schools. Appendix Table 12 provides estimates for middle/high students that test whether the uniform impacts vary by fifth grade achievement where we identify achievement quartiles based on districtwide performance. The results suggest that the attendance improvements from uniforms are most prominent in low achieving students. Finally in Appendix Table 13 we run the same 
analysis but use within high-school quartiles. Results are similar.

\subsection{Impacts on Achievement}

It is intriguing to see whether the improvements found in attendance rates spill over into achievement. Additionally, as mentioned in the introduction, there are a number of other reasons why uniforms may affect achievement directly. Hence, in this section we consider the impact of uniform adoption on students' test score outcomes. All test scores are standardized across LUSD within year and grade, therefore estimates are provided in standard deviation units. We also use annual changes (gains) in achievement as our outcome measures so that we can better account for value-added of schools to the student's performance. ${ }^{25}$

Table 7 provides our main achievement results for elementary and middle/high respectively ${ }^{26}$ The table is structured as in Table $4 .{ }^{27}$ While the estimates are generally negative, in only one instance - elementary female reading - is the effect statistically significant. The results are similar when we add principal fixed-effects. Hence, these results indicate that uniforms have little impact on achievement gains.

In Figure 4 we provide event-study graphs of the impact estimates for achievement gains similar to those provided for attendance and discipline in Figures 2 and 3.28 One potential complication highlighted in this figure is that there appears to be some evidence of pre-adoption trends. In particular, the figures suggest that schools adopt uniforms after achievement gains fall. However, upon closer examination these trends are not as problematic as they initially seem. First, for elementary schools while there is a drop up to 3 years prior to adoption in all three exams, achievement growth flattens and remains roughly constant afterwards until uniform adoption. Hence, we can check whether this trending affects the results by estimating models that drop all observations more than three years prior to

\footnotetext{
${ }^{25}$ Online Appendix Table 14 provides levels models for comparison.

${ }^{26}$ Online Appendix Table 2B provides counts for each of the fixed-effects in these models.

${ }^{27}$ We also estimated basic OLS models that control only for observable characteristics of students. These results showed slightly negative, but insignificant correlations of uniform status with achievement gains of up to 0.03 standard deviations. This is consistent with the findings of Yeung (2009).

${ }^{28}$ Coefficients and standard errors are provided in Online Appendix Tables 15 and 16.
} 
uniform adoption. These results are provided in Online Appendix Table 17 and are similar to the results in Table 7, indicating that the trending in those years have little effect on our estimates. For middle schools there appears to be little evidence of trending in math or reading. Nonetheless, language achievement does seem to fall consistently throughout the graph. However, the drop-off prior to adoption is relatively small and the post-adoption estimates suggest that uniforms did little to either counteract or exacerbate this trend. Post-adoption achievement is relatively flat in all other cases, consistent with the results in Table 7.

As with discipline and attendance we also estimated models that interact uniform status with whether uniforms are adopted under new principals. These are provided in Online Appendix Table 5 and show no significant difference by principal experience. We also analyze heterogeneity by student race and school racial composition. These are provided in Online Appendix Table 18 and do not show consistent patterns across achievement exams. Further, we provide estimates that drop early and late adopters, limit to students who take all three exams, estimate heterogeneous effects by grade level within elementary and middle/high grades, interact uniform status with the student's economic disadvantaged status and disadvantaged rates in the school, and interact uniform status with the student's fifth grade achievement quartile (middle/high only). These are provided along with the attendance and discipline results in Online Appendix Tables 8 - 13. In general the estimates differ little from baseline. The key exceptions are that math achievement effects are significantly higher for students in the bottom quartile of their own school's distribution and students who are not disadvantaged experience some improvements in language scores.

\subsection{Impacts on Student Movements, Grade Retention, and Teacher Attrition}

In Table 8 we provide impact estimates for some alternative outcomes of interest ${ }^{29}$ A possible explanation for the results in Table 4 is that certain types of students are more or

\footnotetext{
${ }^{29}$ Counts of fixed effects are provided in Online Appendix Table 2B
} 
less likely to change schools as a result of uniforms. If this is the case, then we may have attrition bias. However, such behavior would also be interesting in its own right as student movements could provide insight into whether parents see uniforms as beneficial. If students are less likely to leave a school after uniforms are adopted, this potentially shows a revealed preference by parents for uniforms and their behavioral benefits. Hence, in panels A and B we estimate linear probability models of whether uniforms affect the likelihood of students to switch schools within LUSD or leave the district 30 We drop students who are in the highest grades of their school since a school's uniform policy would no longer apply for students who are graduating or leaving to attend another school due to normal grade progression. Hence including these students may lead to biased estimates 131 We find no statistically significant impacts of uniforms on either school switching or district leaving, with the exception of a marginally significant reduction in leaving for middle/high females when we include principal fixed-effects. Nonetheless, this potential effect is economically small and hence overall the results indicate that our estimates for other outcomes are unlikely to be biased due to attrition.

In panel $\mathrm{C}$ we investigate whether uniforms have any impact on grade retention. Unfortunately, our data does not provide us with direct measures of retention. Instead we identify a student as having been retained if his or her grade level is less than or equal to their grade level the prior year. Note that this limits the analysis to students who are enrolled in LUSD both in the current and prior year. In models with school and student fixed-effects, we find a marginally significant reduction in grade retention for males in both elementary and middle/high schools. However, when we add principal fixed-effects, the estimates drop to statistical insignificance. Hence, the results do not provide compelling evidence of an impact of uniforms on grade retention.

In panel $\mathrm{D}$ we estimate the impact of uniforms on teacher attrition using school-year

\footnotetext{
${ }^{30}$ Leavers in middle/high also include dropouts. While it would be interesting to look at dropouts separately, our data on dropouts is unreliable due to misreporting of some dropouts as leaving for other reasons.

${ }^{31}$ Results are similar if we do not make this restriction.
} 
level observations. To calculate attrition rates we identify teachers using their first and last names. If a name does not appear in the same school the following year, we count that as an attrition. Note that this will likely lead us calculate attrition rates that are too large as we will count a name change as an attrition. This should only be a problem, however, if the likelihood of a teacher changing his or her name is correlated with uniform adoption, which we believe to be highly unlikely. In addition to school fixed-effects, the model controls for year indicators and the share of students in the school enrolled in each grade, female, free lunch, reduced-price lunch, other economic disadvantage, black, Hispanic, and white. The results show a significant reduction in teacher attrition after the adoption of uniforms in elementary schools of 5 percentage points. This is a large effect relative to the mean attrition rate of $25 \%$. When we add principal fixed-effects the estimate reduces to 4 percentage points but remains significant at the $10 \%$ level. For middle school the point estimates are also negative, but smaller and statistically insignificant. In order to investigate this result further, we provide event study graphs in Figure 5. The figure shows a notable drop in attrition for elementary schools during the year of uniform adoption that remains at the new level thereafter. There is also little indication of trending prior to adoption.

\section{Conclusion}

Concerns about school safety and the desire by administrators to try different strategies to improve test scores and behavior has led many schools to adopt student uniforms. However, the current evidence on uniforms is sparse and the existing research relies on cross-sectional variation. Since schools likely adopt uniforms in response to poor behavior or achievement the results from this research may suffer from substantial bias.

In this paper we assess whether requiring uniforms in schools affects student outcomes using administrative data from a large urban school district in the southwest United States. Since schools in this district independently decide whether or not to adopt uniforms over 
the time period for which we have data, we are able to incorporate school fixed-effects and student fixed-effects into our regressions. This allows us to account for schools endogenously deciding to adopt uniforms off of their fixed characteristics as well as students' selection into uniform schools provided that such selection is based on students' fixed characteristics. These corrections are very important as evidenced by the fact that while most prior work has found uniforms to have insignificant to negative impacts, we find that uniforms have a positive influence on student attendance in secondary grades. Attendance rates in grades 6 through 12 increase by 0.3 to 0.4 percentage points after a school adopts uniforms. On the other hand, we find little evidence that uniforms have lasting impacts on achievement, grade retention, or the likelihood of students switching schools or leaving the district for all genders and grade levels.

In terms of discipline we also find little evidence of uniform effects. We note that these results are inconsistent with an alternative theory of concurrent strengthening of enforcement policies, since if this were the case we'd expect to see at least a temporary increase. We also provide evidence from models that include principal fixed-effects to account for the disciplinary philosophy and quality of school leadership and from models that consider whether uniform impacts vary by whether uniforms are adopted by a principal who is new to a school. New principals are likely to be more inclined to adopt changes in many parts of a school besides uniform adoption and sometimes may be brought in to "shake-up" a school. Our results are robust to both of these specifications. Nor do we find significant changes in the severity of punishments. Hence, we believe that our estimates isolate the impacts of uniforms from potential changes in enforcement, although we cannot rule out the possibility that uniforms are adopted concurrently with other policies.

Finally, we find that uniforms generate significant reductions in teacher attrition in elementary schools on the order of 5 percentage points. This is a large effect relative to the mean of $25 \%$ annual attrition. 


\section{References}

Alspach, Kyle, "Measured Look at Uniforms: Alternative to Dress Code," Boston Globe, May 172007.

Anonymous, "School Uniform Costs Vary Widely," BBC.com, May 92003.

_ _ "Council Recommends Uniforms at All City Schools," Los Angeles Daily News, November 42009.

__ , "School Uniforms - Yes, But," Los Angeles Times, December 92009.

Archibold, Randal C., "Advocates of School Uniform Plan Enlist Children to Help Make Their Case," New York Times, February 261998.

Bodine, Ann, "School Uniforms, Academic Achievement, and Uses of Research," The Journal of Educational Research, 2003, 97 (2), 67-73.

Boyd, Don, Hamp Lankford, Susanna Loeb, Mathhew Ronfeldt, and Jim Wyckoff, "The Role of Teacher Quality in Retention and Hiring: Using Applications to Transfer to Uncovere Preferences of Teachers and Schools," Journal of Policy Analysis and Management, 2010, 30 (1), 88-110.

Brunsma, David L., The School Uniform Movement and What it Tells Us About American Education, Scarecrow Education, 2004.

and Kerry A. Rockquemore, "Effects of Student Uniforms on Attendance, Behavior Problems, Substance Abuse, and Academic Achievements," The Journal of Educational Research, 1998, 92 (1).

Carrell, Scott and Mark Hoekstra, "Externalities in the Classroom: How Children Exposed to Domestic Violence Affect Everyone's Kids," American Economic Journal: Applied Economics, January 2010, 2 (1), 211-228. 
Clotfelter, Charles T., Elizabeth J. Glennie, Helen F. Ladd, and Jacob L. Vigdor, "Teacher Bonuses and Teacher Retention in Low Performing Schools: Evidence from the North Carolina \$1800 Teacher Bonus Program," Public Finance Review, 2008, 36 (1), 63-87.

Evans, David, Michael Kremer, and Muthoni Ngatia, "The Impact of Distributing School Uniforms on Children's Education in Kenya," World Bank, mimeo, 2008.

Feng, Li, "Hire Today, Gone Tomorrow: New Teacher Classroom Assignments and Teacher Mobility," Education Finance and Policy, 2010, 5 (3), 278-316.

Figlio, David, "Boys Named Sue; Disruptive Children and Their Peers," Education Finance and Policy, Fall 2007, 2 (4), 376-394.

Gaviria, Alejandro and Steven Raphel, "School-Based Peer Effects and Juvenile Behavior," Review of Economics and Statistics, 2001, 83, 257-268.

Heckman, James J. and Yona Rubinstein, "The Importance of Noncognitive Skills: Lessons from the GED Testing Program," The American Economic Review - Papers and Proceedings, 2001, 91 (2), 145-149.

, Jora Stixrud, and Sergio Urzua, "The Effects of Cognitive and Noncognitive Abilities on Labor Market Outcomes and Social Behavior," Journal of Labor Economics, 2006, $24(3), 411-482$.

Imberman, Scott A., "Achievement and Behavior of Charter Students: Drawing a More Complete Picture," Review of Economics and Statistics, 2011, 93 (2), 416-435.

Adriana D. Kugler, and Bruce I. Sacerdote, "Katrina's Children: Evidence on The Structure of Peer Effects from Hurricane Evacuees," American Economic Review, forthcoming. 
Jacob, Brian A., "Where the Boys Aren't: Non-Cognitive Skills, Returns to School, and the Gender Gap in Higher Education," Economics of Education Review, 2002, 21 (6), 589598.

Mitchell, Alison, "Clinton Will Advise Schools on Uniforms," New York Times, February 25 1996.

Rivkin, Steven G., Eric A. Hanushek, and John F. Kain, "Teachers, Schools and Academic Achievement," Econometrica, 2005, 73 (2), 417-458.

Segal, Carmit, "Classroom Behavior," Journal of Human Resources, Fall 2009, 43 (4), 783-814.

Stanley, M.Sue, "School Uniforms and Safety," Education and Urban Society, 1996, 28 (4), 424.

Steinberg, Jacques, "Guilianai Says He Supports Plan for Requiring School Uniforms," New York Times, February 121998.

Wade, Kathleen K. and Mary E. Stafford, "Public School Uniforms: Effect on Perceptions of Gang Presence, School Climate, and Student Self-Perceptions," Education and Urban Society, 2003, 35 (4), 399.

Watlington, Eliah, Robert Shockley, Paul Guglielmino, and Rivka Felsher, "The High Cost of Leaving: An Analysis of the Cost of Teacher Turnover," Journal of Education Finance, 2010, 36 (1), 22-37.

Wooldridge, Jeffrey M., Econometric Analysis of Cross Section and Panel Data, MIT Press, 2002.

Yeung, Ryan, "Are Uniforms a Good Fit?: Results from the ECLS-K and the NELS," Educational Policy, 2009, 23 (6), 847-874. 
Figure 1: Uniform Adoption in LUSD-SW

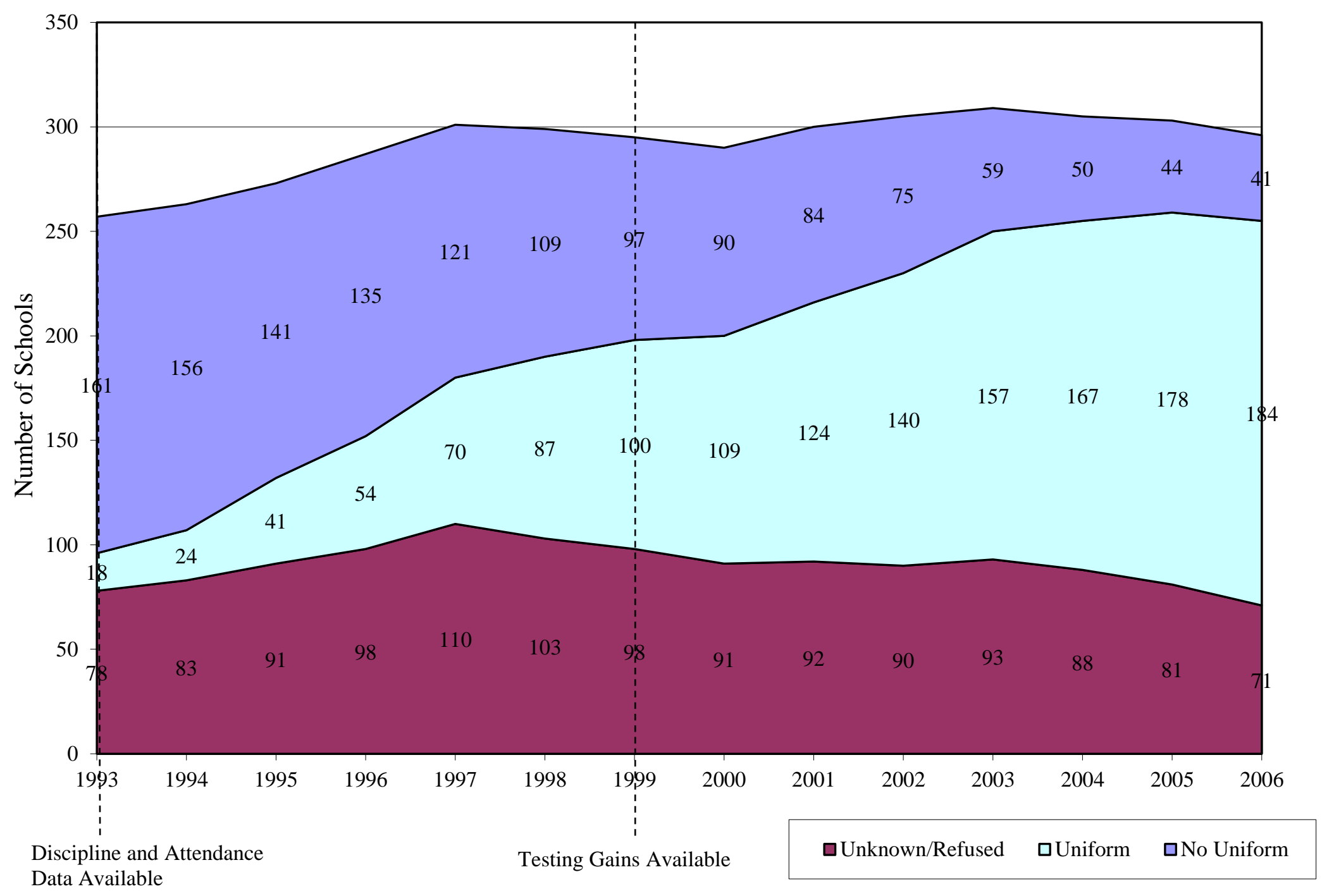


Figure 2: Attendance Before and After Uniform Adoption

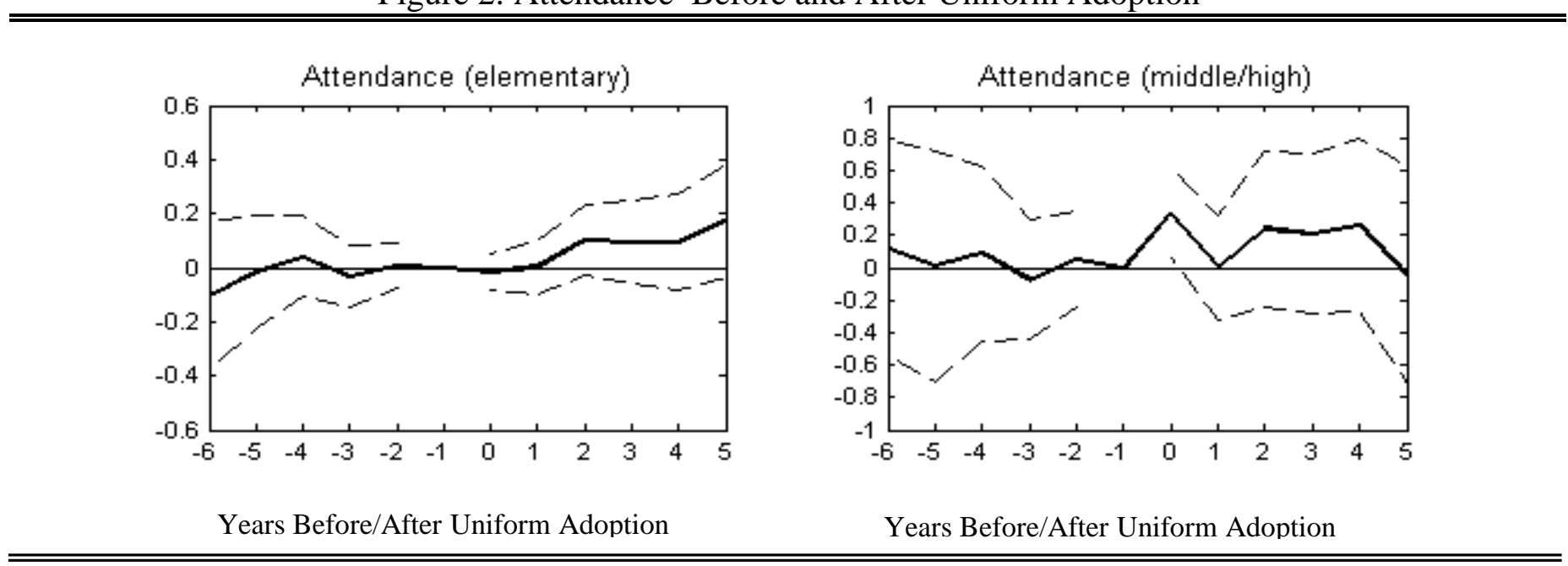

Graphs show point estimates and 95\% confidence intervals for estimates from regressions of the outcome on indicators for each year prior to and after uniform adoption (year $\mathrm{t}=-1$ is omitted), grade-by-year indicators, student economic status, student fixed-effects and school fixed-effects. Numerical values are provided in Online Appendix Tables 6 and 7. 
Figure 3: Discipline Before and After Uniform Adoption
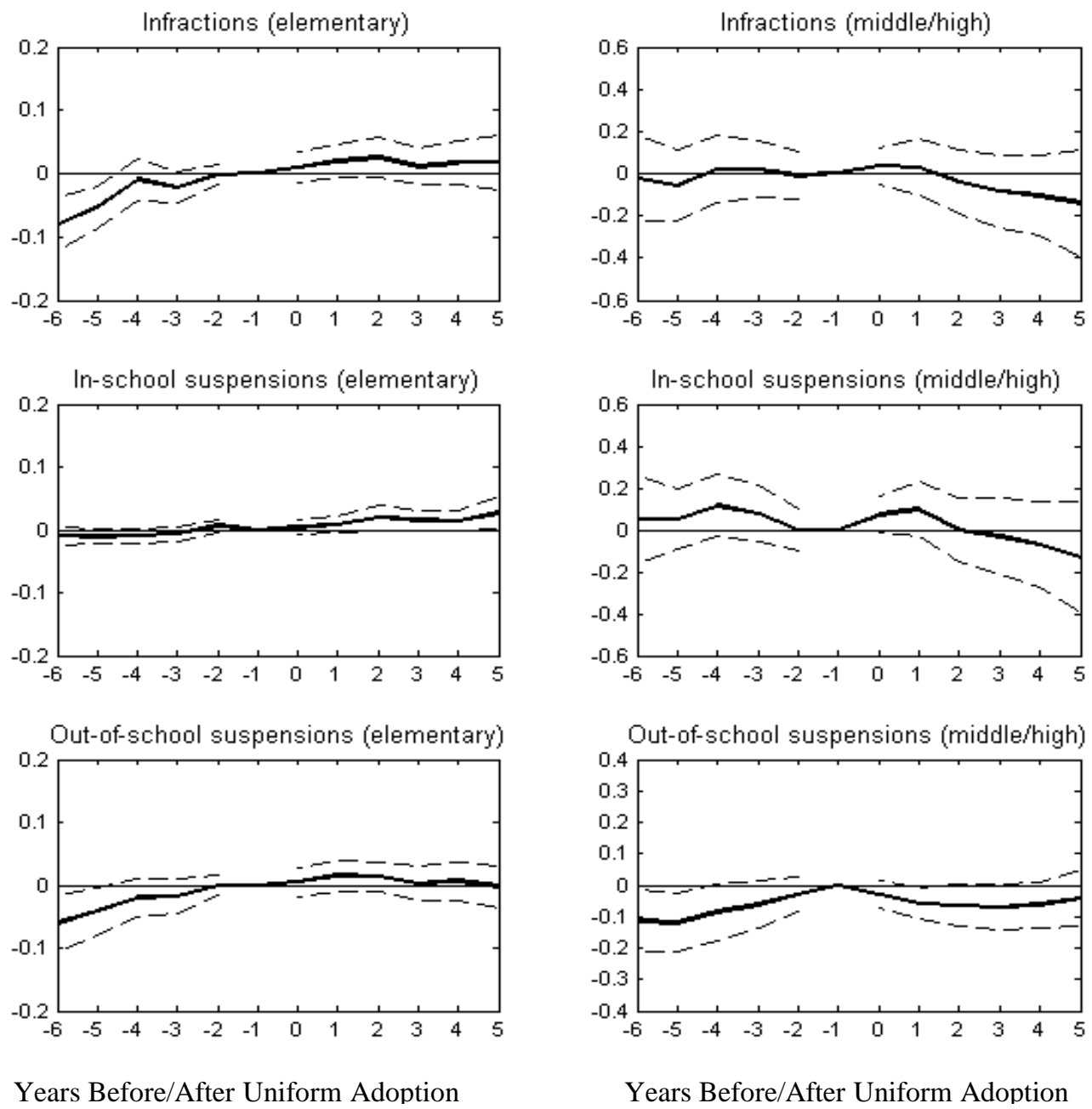

Years Before/After Uniform Adoption

Years Before/After Uniform Adoption

Graphs show point estimates (solid line) and 95\% confidence intervals (dotted lines) for estimates from regressions of the outcome on indicators for each year prior to and after uniform adoption (year $t=-1$ is omitted), grade-by-year indicators, student economic status, student fixed-effects and school fixed-effects. Numerical values are provided in Online Appendix Tables 6 and 7. 

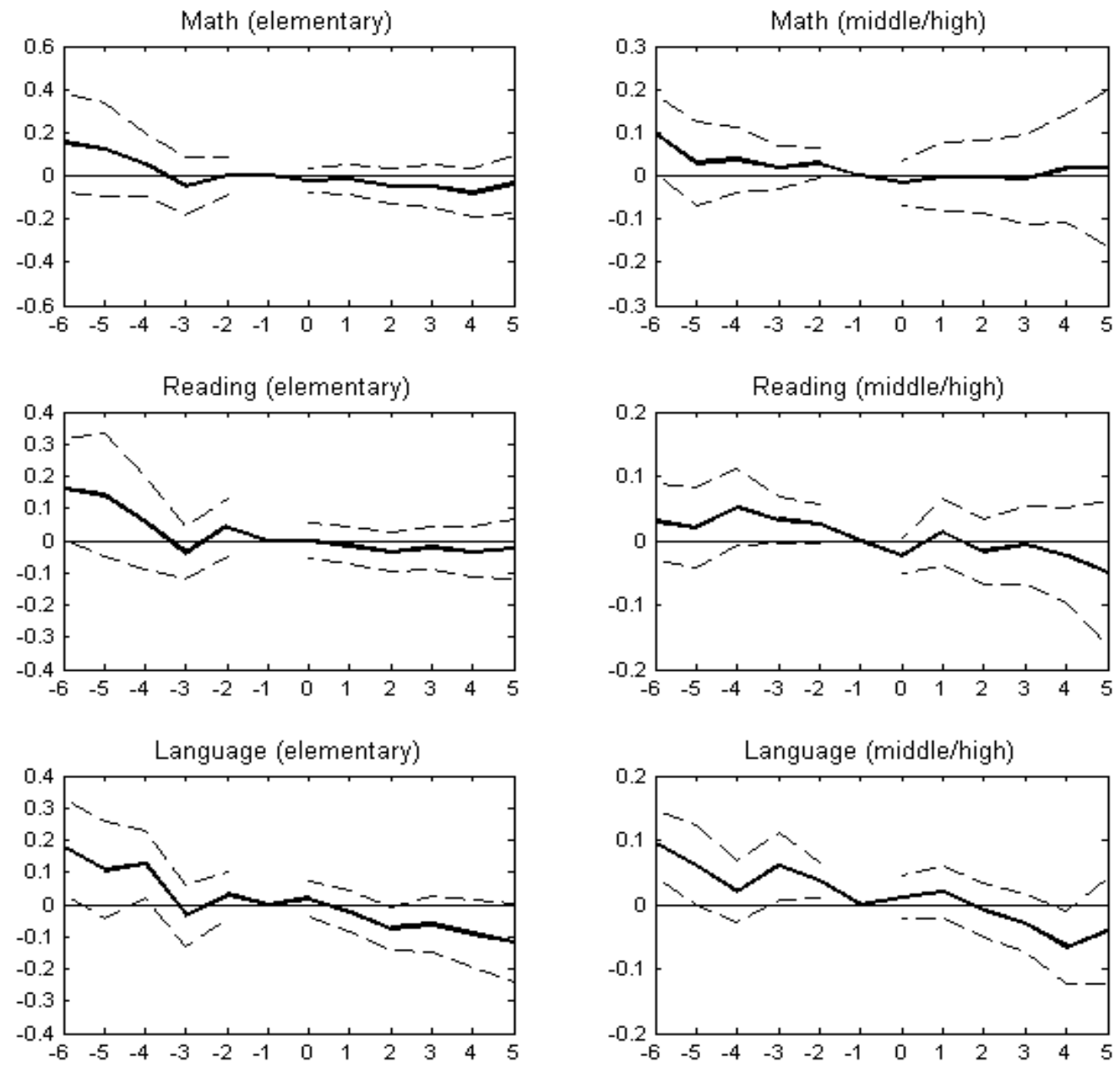

Years Before/After Uniform Adoption

Years Before/After Uniform Adoption

Graphs show point estimates and 95\% confidence intervals for estimates from regressions of the outcome on indicators for each year prior to and after uniform adoption (year $\mathrm{t}=-1$ is omitted), grade-by-year indicators, student economic status, student fixed-effects and school fixed-effects. Numerical values are provided in Online Appendix Tables 15 an 16. 
Figure 5: Teacher Attrition Before and After Uniform Adoption
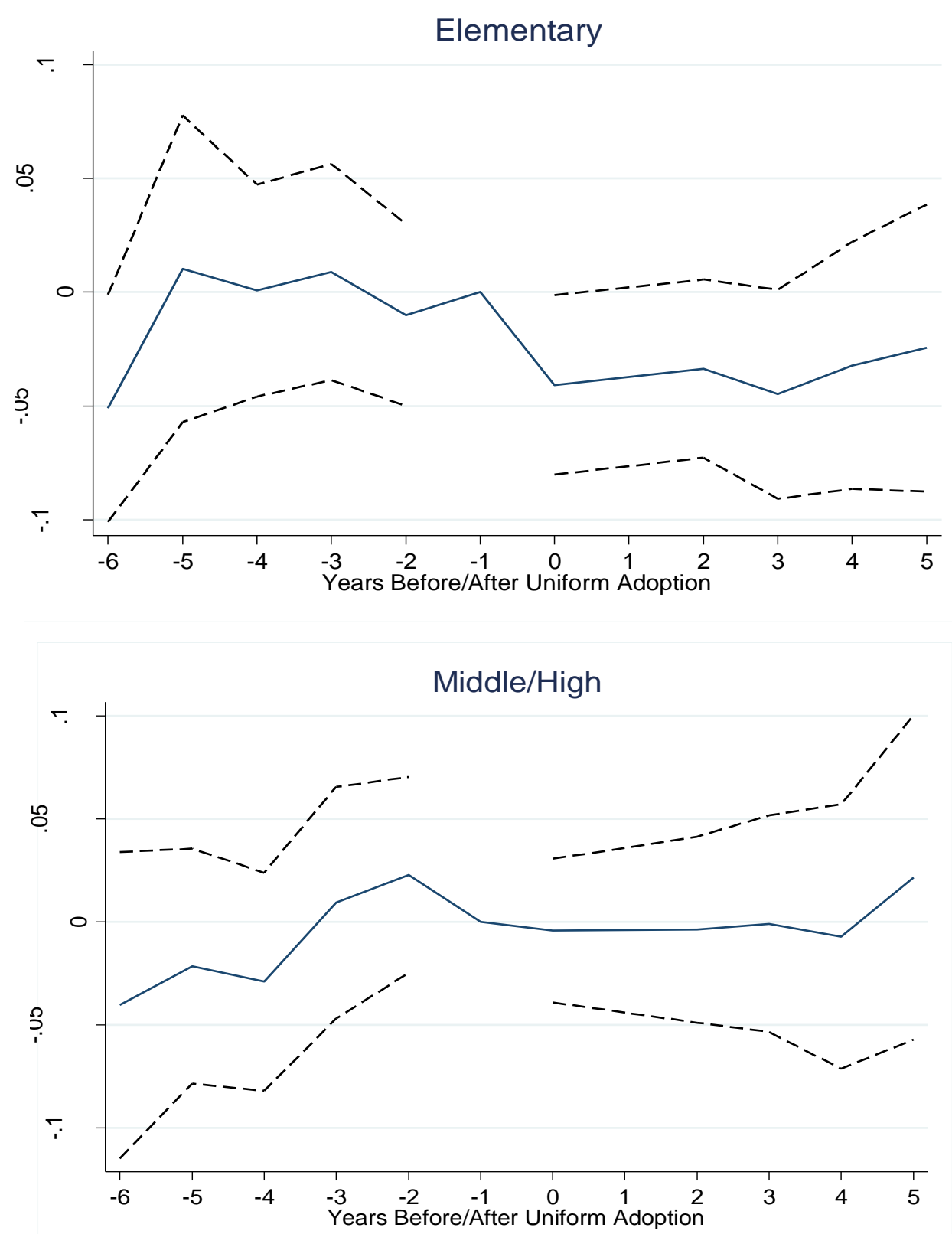

Graphs show point estimates and 95\% confidence intervals for estimates from regressions of the outcome on indicators for each year prior to and after uniform adoption (year $t=-1$ is omitted), year indicators, share of school eligible for free-lunch, eligible for reduced-price lunch, otherwise economically disadvantaged, African-American, Hispanic, white, female, in each grade and and school fixed-effects. Numerical values are provided in Online Appendix Table 19. 
Table 1: School Characteristics in 1993

\begin{tabular}{|c|c|c|c|c|c|c|}
\hline & \multicolumn{3}{|c|}{ Elementary } & \multicolumn{3}{|c|}{ Middle/High } \\
\hline & $\begin{array}{c}\text { Early } \\
\text { Adopter }\end{array}$ & $\begin{array}{c}\text { Late } \\
\text { Adopter }\end{array}$ & $\begin{array}{c}\text { Never } \\
\text { Adopter }\end{array}$ & $\begin{array}{c}\text { Early } \\
\text { Adopter }\end{array}$ & $\begin{array}{c}\text { Late } \\
\text { Adopter }\end{array}$ & $\begin{array}{c}\text { Never } \\
\text { Adopter }\end{array}$ \\
\hline Female & $\begin{array}{c}0.49 \\
(0.02)\end{array}$ & $\begin{array}{c}0.49 \\
(0.03)\end{array}$ & $\begin{array}{c}0.49 \\
(0.03)\end{array}$ & $\begin{array}{c}0.49 \\
(0.10)\end{array}$ & $\begin{array}{c}0.49 \\
(0.03)\end{array}$ & $\begin{array}{c}0.48 \\
(0.05)\end{array}$ \\
\hline Black & $\begin{array}{c}0.31 \\
(0.33)\end{array}$ & $\begin{array}{c}0.46^{* *} \\
(0.31)\end{array}$ & $\begin{array}{c}0.25 \\
(0.30)\end{array}$ & $\begin{array}{c}0.40 \\
(0.30)\end{array}$ & $\begin{array}{c}0.46 \\
(0.36)\end{array}$ & $\begin{array}{c}0.43 \\
(0.34)\end{array}$ \\
\hline Hispanic & $\begin{array}{c}0.53 \\
(0.33)\end{array}$ & $\begin{array}{c}0.42 \\
(0.29)\end{array}$ & $\begin{array}{c}0.41 \\
(0.33)\end{array}$ & $\begin{array}{c}0.44 \\
(0.27)\end{array}$ & $\begin{array}{c}0.44 \\
(0.34)\end{array}$ & $\begin{array}{c}0.31 \\
(0.26)\end{array}$ \\
\hline White & $\begin{array}{c}0.14 \\
(0.19)\end{array}$ & $\begin{array}{c}0.09 \\
(0.14)\end{array}$ & $\begin{array}{c}0.30 * * \\
(0.14)\end{array}$ & $\begin{array}{c}0.14 \\
(0.14)\end{array}$ & $\begin{array}{c}0.08 \\
(0.11)\end{array}$ & $\begin{array}{c}0.21 \\
(0.21)\end{array}$ \\
\hline Free Lunch & $\begin{array}{c}0.68 \\
(0.22)\end{array}$ & $\begin{array}{c}0.69 \\
(0.18)\end{array}$ & $\begin{array}{c}0.46^{* *} \\
(0.29)\end{array}$ & $\begin{array}{c}0.46 \\
(0.16)\end{array}$ & $\begin{array}{c}0.40 \\
(0.17)\end{array}$ & $\begin{array}{c}0.21 * * * \\
(0.11)\end{array}$ \\
\hline Reduced Price Lunch & $\begin{array}{c}0.04 \\
(0.02)\end{array}$ & $\begin{array}{c}0.04 \\
(0.02)\end{array}$ & $\begin{array}{c}0.04 \\
(0.02)\end{array}$ & $\begin{array}{c}0.02 \\
(0.01)\end{array}$ & $\begin{array}{c}0.01 \\
(0.01)\end{array}$ & $\begin{array}{c}0.01 * * * \\
(0.01)\end{array}$ \\
\hline $\begin{array}{l}\text { Limited English } \\
\text { Proficiency }\end{array}$ & $\begin{array}{c}0.32 \\
(0.21)\end{array}$ & $\begin{array}{c}0.28 \\
(0.21)\end{array}$ & $\begin{array}{c}0.24 \\
(0.24)\end{array}$ & $\begin{array}{c}0.15 \\
(0.12)\end{array}$ & $\begin{array}{c}0.15 \\
(0.13)\end{array}$ & $\begin{array}{c}0.10 \\
(0.13)\end{array}$ \\
\hline At Risk Status & $\begin{array}{c}0.56 \\
(0.17)\end{array}$ & $\begin{array}{c}0.55 \\
(0.16)\end{array}$ & $\begin{array}{l}0.44 * \\
(0.23)\end{array}$ & $\begin{array}{c}0.59 \\
(0.18)\end{array}$ & $\begin{array}{l}0.68 * \\
(0.14)\end{array}$ & $\begin{array}{c}0.56 \\
(0.29)\end{array}$ \\
\hline Special Education & $\begin{array}{c}0.10 \\
(0.03)\end{array}$ & $\begin{array}{c}0.10 \\
(0.04)\end{array}$ & $\begin{array}{c}0.10 \\
(0.04)\end{array}$ & $\begin{array}{c}0.16 \\
(0.19)\end{array}$ & $\begin{array}{c}0.12 \\
(0.05)\end{array}$ & $\begin{array}{c}0.20 \\
(0.25)\end{array}$ \\
\hline Gifted and Talented & $\begin{array}{c}0.08 \\
(0.12)\end{array}$ & $\begin{array}{c}0.06 \\
(0.10)\end{array}$ & $\begin{array}{c}0.21 \\
(0.27)\end{array}$ & $\begin{array}{c}0.11 \\
(0.17)\end{array}$ & $\begin{array}{l}0.04 * \\
(0.08)\end{array}$ & $\begin{array}{c}0.22 \\
(0.36)\end{array}$ \\
\hline $\begin{array}{c}\text { TAAS Math } \\
\text { Pass Rate }\end{array}$ & $\begin{array}{c}0.37 \\
(0.15)\end{array}$ & $\begin{array}{c}0.38 \\
(0.17)\end{array}$ & $\begin{array}{c}0.51^{* *} \\
(0.19)\end{array}$ & $\begin{array}{c}0.33 \\
(0.19)\end{array}$ & $\begin{array}{c}0.27 \\
(0.11)\end{array}$ & $\begin{array}{c}0.46 \\
(0.20)\end{array}$ \\
\hline $\begin{array}{c}\text { TAAS Reading } \\
\text { Pass Rate }\end{array}$ & $\begin{array}{c}0.50 \\
(0.15)\end{array}$ & $\begin{array}{c}0.49 \\
(0.16)\end{array}$ & $\begin{array}{c}0.62 * * \\
(0.18)\end{array}$ & $\begin{array}{c}0.44 \\
(0.20)\end{array}$ & $\begin{array}{c}0.38 \\
(0.09)\end{array}$ & $\begin{array}{c}0.49 \\
(0.19)\end{array}$ \\
\hline Disciplinary Infraction & $\begin{array}{c}0.039 \\
(0.060)\end{array}$ & $\begin{array}{c}0.027 \\
(0.023)\end{array}$ & $\begin{array}{c}0.024 \\
(0.025)\end{array}$ & $\begin{array}{c}0.54 \\
(0.36)\end{array}$ & $\begin{array}{c}0.44 \\
(0.39)\end{array}$ & $\begin{array}{c}0.17 * * * \\
(0.12)\end{array}$ \\
\hline Attendance Rate & $\begin{array}{l}95.9 \\
(0.9)\end{array}$ & $\begin{array}{l}95.6 \\
(1.1)\end{array}$ & $\begin{array}{l}96.3 \\
(0.8)\end{array}$ & $\begin{array}{l}92.1 \\
(6.4)\end{array}$ & $\begin{array}{l}92.1 \\
(3.1)\end{array}$ & $\begin{array}{l}93.4 \\
(2.3)\end{array}$ \\
\hline Observations & 72 & 30 & 14 & 21 & 22 & 9 \\
\hline
\end{tabular}

Early adopters adopt uniforms prior to 2001 Late adopters adopt from 2001 to 2007. Standard deviations in parentheses. Means shown in table are unweighted averages over school-level means. *, **, *** denote that mean is significantly different from early adopters at the $10 \%, 5 \%$, and $1 \%$ levels, respectively. 


\begin{tabular}{|c|c|c|c|c|c|c|}
\hline & \multicolumn{3}{|c|}{ Elementary } & \multicolumn{3}{|c|}{ Middle/High } \\
\hline & $\begin{array}{c}\text { Uniform Not } \\
\text { Required } \\
\end{array}$ & $\begin{array}{l}\text { Uniform } \\
\text { Required }\end{array}$ & Unknown & $\begin{array}{c}\text { Uniform Not } \\
\text { Required } \\
\end{array}$ & $\begin{array}{l}\text { Uniform } \\
\text { Required }\end{array}$ & Unknown \\
\hline & \multicolumn{6}{|c|}{ A. Demographics } \\
\hline Female & $\begin{array}{c}0.49 \\
(0.50)\end{array}$ & $\begin{array}{c}0.49 \\
(0.50)\end{array}$ & $\begin{array}{c}0.49 \\
(0.50)\end{array}$ & $\begin{array}{c}0.49 \\
(0.50)\end{array}$ & $\begin{array}{l}0.51 * \\
(0.50)\end{array}$ & $\begin{array}{c}0.48 \\
(0.50)\end{array}$ \\
\hline Black & $\begin{array}{c}0.30 \\
(0.46)\end{array}$ & $\begin{array}{c}0.27 \\
(0.44)\end{array}$ & $\begin{array}{l}0.41^{*} \\
(0.49)\end{array}$ & $\begin{array}{c}0.36 \\
(0.48)\end{array}$ & $\begin{array}{c}0.30 \\
(0.46)\end{array}$ & $\begin{array}{c}0.33 \\
(0.47)\end{array}$ \\
\hline Hispanic & $\begin{array}{c}0.52 \\
(0.50)\end{array}$ & $\begin{array}{l}0.60 * * \\
(0.49)\end{array}$ & $\begin{array}{c}0.53 \\
(0.50)\end{array}$ & $\begin{array}{c}0.48 \\
(0.50)\end{array}$ & $\begin{array}{c}0.58^{* *} \\
(0.49)\end{array}$ & $\begin{array}{c}0.53 \\
(0.50)\end{array}$ \\
\hline White & $\begin{array}{c}0.15 \\
(0.35)\end{array}$ & $\begin{array}{l}0.10^{*} \\
(0.30)\end{array}$ & $\begin{array}{l}0.04^{* *} \\
(0.19)\end{array}$ & $\begin{array}{c}0.12 \\
(0.33)\end{array}$ & $\begin{array}{c}0.09 * * \\
(0.28)\end{array}$ & $\begin{array}{c}0.11 \\
(0.31)\end{array}$ \\
\hline Free Lunch & $\begin{array}{c}0.65 \\
(0.48)\end{array}$ & $\begin{array}{c}0.67 \\
(0.47)\end{array}$ & $\begin{array}{c}0.77 * * * \\
(0.42)\end{array}$ & $\begin{array}{c}0.43 \\
(0.50)\end{array}$ & $\begin{array}{c}0.58 * * * \\
(0.49)\end{array}$ & $\begin{array}{l}0.54^{*} \\
(0.50)\end{array}$ \\
\hline Reduced Price Lunch & $\begin{array}{c}0.07 \\
(0.25)\end{array}$ & $\begin{array}{c}0.09 * * * \\
(0.29)\end{array}$ & $\begin{array}{l}0.08 * * \\
(0.26)\end{array}$ & $\begin{array}{c}0.04 \\
(0.20)\end{array}$ & $\begin{array}{c}0.09 * * * \\
(0.29)\end{array}$ & $\begin{array}{c}0.06^{* * *} \\
(0.24)\end{array}$ \\
\hline $\begin{array}{l}\text { Limited English } \\
\text { Proficiency }\end{array}$ & $\begin{array}{c}0.34 \\
(0.47)\end{array}$ & $\begin{array}{c}0.37 \\
(0.48)\end{array}$ & $\begin{array}{c}0.35 \\
(0.48)\end{array}$ & $\begin{array}{c}0.15 \\
(0.36)\end{array}$ & $\begin{array}{c}0.13 \\
(0.34)\end{array}$ & $\begin{array}{c}0.16 \\
(0.37)\end{array}$ \\
\hline At Risk Status & $\begin{array}{c}0.52 \\
(0.50)\end{array}$ & $\begin{array}{c}0.59 * * * \\
(0.49)\end{array}$ & $\begin{array}{l}0.58 * \\
(0.50)\end{array}$ & $\begin{array}{c}0.58 \\
(0.49)\end{array}$ & $\begin{array}{c}0.59 \\
(0.49)\end{array}$ & $\begin{array}{c}0.58 \\
(0.49)\end{array}$ \\
\hline Special Education & $\begin{array}{c}0.10 \\
(0.30)\end{array}$ & $\begin{array}{l}0.09 * \\
(0.29)\end{array}$ & $\begin{array}{c}0.10 \\
(0.29)\end{array}$ & $\begin{array}{c}0.12 \\
(0.33)\end{array}$ & $\begin{array}{c}0.13 \\
(0.33)\end{array}$ & $\begin{array}{c}0.13 \\
(0.34)\end{array}$ \\
\hline Gifted and Talented & $\begin{array}{c}0.12 \\
(0.32)\end{array}$ & $\begin{array}{c}0.11 \\
(0.31)\end{array}$ & $\begin{array}{c}0.05^{* * *} \\
(0.22)\end{array}$ & $\begin{array}{c}0.12 \\
(0.33)\end{array}$ & $\begin{array}{c}0.12 \\
(0.32)\end{array}$ & $\begin{array}{c}0.10 \\
(0.30)\end{array}$ \\
\hline Observations & 402,728 & 490,802 & 323,302 & 704,605 & 368,928 & 204,752 \\
\hline & & & B. Ou & comes & & \\
\hline Stanford Math & $\begin{array}{c}0.15 \\
(1.07)\end{array}$ & $\begin{array}{c}0.00 \\
(0.98)\end{array}$ & $\begin{array}{c}-0.13^{* * *} \\
(0.96)\end{array}$ & $\begin{array}{c}0.01 \\
(1.04)\end{array}$ & $\begin{array}{c}0.01 \\
(0.98)\end{array}$ & $\begin{array}{l}-0.05 \\
(0.95)\end{array}$ \\
\hline Observations & 117,571 & 288,711 & 140,731 & 259,019 & 280,540 & 106,024 \\
\hline Stanford Reading & $\begin{array}{c}0.19 \\
(1.09)\end{array}$ & $\begin{array}{l}0.00 * \\
(0.98)\end{array}$ & $\begin{array}{c}-0.16^{* * *} \\
(0.93)\end{array}$ & $\begin{array}{c}0.00 \\
(1.03)\end{array}$ & $\begin{array}{c}0.01 \\
(0.99)\end{array}$ & $\begin{array}{c}-0.03 \\
0.96\end{array}$ \\
\hline Observations & 117,522 & 288,343 & 140,719 & 258,511 & 280,860 & 106,289 \\
\hline Stanford Language & $\begin{array}{c}0.17 \\
(1.08)\end{array}$ & $\begin{array}{c}0.00 \\
(0.98)\end{array}$ & $\begin{array}{c}-0.15^{* * *} \\
(0.94)\end{array}$ & $\begin{array}{c}0.01 \\
(1.03)\end{array}$ & $\begin{array}{c}0.02 \\
(0.99)\end{array}$ & $\begin{array}{l}-0.07 \\
(0.96)\end{array}$ \\
\hline Observations & 117,604 & 288,718 & 140,792 & 258,077 & 280,291 & 105,879 \\
\hline Disciplinary Infractions & $\begin{array}{c}0.06 \\
(0.40)\end{array}$ & $\begin{array}{c}0.09 * * * \\
(0.50)\end{array}$ & $\begin{array}{c}0.10 * * * \\
(0.55)\end{array}$ & $\begin{array}{c}0.64 \\
(1.60)\end{array}$ & $\begin{array}{c}0.92 * * * \\
(2.00)\end{array}$ & $\begin{array}{l}0.82 * \\
(1.85)\end{array}$ \\
\hline Observations & 402,728 & 490,802 & 323,302 & 704,605 & 368,928 & 204,752 \\
\hline Attendance Rate & $\begin{array}{l}96.1 \\
(6.4)\end{array}$ & $\begin{array}{c}96.7 * * * \\
(4.1)\end{array}$ & $\begin{array}{l}96.1 \\
(5.0)\end{array}$ & $\begin{array}{c}92.2 \\
(11.1)\end{array}$ & $\begin{array}{c}93.7^{* * *} \\
(9.5)\end{array}$ & $\begin{array}{c}92.2 \\
(12.0)\end{array}$ \\
\hline Observations & 389,968 & 488,163 & 317,929 & 687,822 & 367,906 & 200,375 \\
\hline
\end{tabular}

Standard deviations in parentheses. All test scores are measured in standard deviations from the grade-year mean scale score. Elementary includes students in grades 1 through 5. Middle/high includes grades 6 through $12 .{ }^{*}, * *, * * *$ denote that estimates from a regression of the outcome on "uniform required" or "unknown" relative to "uniform not required" is significantly different from early adopters at the $10 \%, 5 \%$, and $1 \%$ levels, respectively. Standard errors in these regressions are clustered by school. 
Table 3: Probit Estimates of Uniform Adoption on Prior-Year School Characteristics

\begin{tabular}{|c|c|c|c|}
\hline & $\begin{array}{l}\text { All Schools } \\
(1)\end{array}$ & $\begin{array}{c}\text { Elementary } \\
(2)\end{array}$ & $\begin{array}{l}\text { Middle/High } \\
\text { (3) }\end{array}$ \\
\hline \multirow[t]{3}{*}{ Enrollment (in thousands) } & $0.278 *$ & $0.449 * *$ & -0.470 \\
\hline & $(0.146)$ & $(0.188)$ & $(0.319)$ \\
\hline & [0.045] & [0.083] & {$[-0.084]$} \\
\hline \multirow[t]{3}{*}{ Female Share } & 1.452 & 1.149 & $4.449 * *$ \\
\hline & $(1.415)$ & $(1.838)$ & $(1.779)$ \\
\hline & [0.237] & [0.205] & {$[0.637]$} \\
\hline \multirow[t]{3}{*}{ Economic Disadvantage Share } & 0.497 & -0.555 & $2.388 * * *$ \\
\hline & $(0.539)$ & $(0.836)$ & $(0.779)$ \\
\hline & {$[0.081]$} & {$[-0.099]$} & {$[0.342]$} \\
\hline \multirow[t]{3}{*}{ Black Share } & $-1.614^{* *}$ & -0.484 & $-3.997 * * *$ \\
\hline & $(0.791)$ & $(0.998)$ & $(1.380)$ \\
\hline & {$[-0.263]$} & {$[-0.086]$} & {$[-0.573]$} \\
\hline \multirow[t]{3}{*}{ Hispanic Share } & -1.396 & -0.235 & $-3.280 * *$ \\
\hline & $(0.876)$ & $(1.135)$ & (1.399) \\
\hline & {$[-0.228]$} & {$[-0.042]$} & {$[-0.470]$} \\
\hline \multirow[t]{3}{*}{ Other Non-White Share } & $-5.657 * *$ & -4.472 & $-9.759 * *$ \\
\hline & $(2.819)$ & $(3.259)$ & $(3.841)$ \\
\hline & {$[-0.923]$} & {$[-0.798]$} & {$[-1.398]$} \\
\hline \multirow[t]{3}{*}{ At-Risk Share } & 0.808 & 1.085 & $2.105^{* *}$ \\
\hline & $(0.648)$ & $(0.950)$ & $(0.930)$ \\
\hline & [0.132] & {$[0.194]$} & [0.302] \\
\hline \multirow[t]{3}{*}{ Special Education Share } & 0.216 & $-2.782 * *$ & $2.636 * *$ \\
\hline & $(0.785)$ & (1.319) & $(1.170)$ \\
\hline & [0.035] & [-0.497] & [0.378] \\
\hline \multirow[t]{3}{*}{ Gifted Share } & $-1.285^{* *}$ & $-1.569 * *$ & 0.621 \\
\hline & $(0.646)$ & $(0.797)$ & (0.613) \\
\hline & {$[-0.210]$} & {$[-0.280]$} & [0.089] \\
\hline \multirow[t]{3}{*}{ LEP Share } & -0.682 & -0.701 & $-2.503^{* *}$ \\
\hline & $(0.657)$ & $(0.980)$ & (1.001) \\
\hline & {$[-0.111]$} & {$[-0.125]$} & [-0.359] \\
\hline \multirow{3}{*}{$\begin{array}{l}\text { Per-Pupil Total Operating Expenditures } \\
\text { (in \$thousands) }\end{array}$} & -0.041 & $-0.171^{* * *}$ & -0.014 \\
\hline & $(0.029)$ & $(0.047)$ & $(0.041)$ \\
\hline & {$[-0.007]$} & {$[-0.031]$} & {$[-0.002]$} \\
\hline \multirow[t]{3}{*}{ Mean Teacher Experience } & 0.083 & 0.002 & 0.137 \\
\hline & $(0.062)$ & (0.069) & $(0.100)$ \\
\hline & [0.014] & {$[0.000]$} & {$[0.020]$} \\
\hline \multirow[t]{3}{*}{ Mean Teacher Tenure } & -0.077 & 0.002 & -0.135 \\
\hline & $(0.066)$ & $(0.072)$ & $(0.101)$ \\
\hline & {$[-0.013]$} & {$[0.000]$} & {$[-0.019]$} \\
\hline \multirow[t]{3}{*}{ Student-Teacher Ratio } & $-0.074 * * *$ & $-0.087 * *$ & -0.014 \\
\hline & $(0.029)$ & $(0.036)$ & $(0.047)$ \\
\hline & {$[-0.012]$} & {$[-0.015]$} & {$[-0.002]$} \\
\hline \multirow[t]{3}{*}{ Mean Attendance Rate } & 0.002 & 0.100 & -0.014 \\
\hline & $(0.027)$ & (0.078) & $(0.034)$ \\
\hline & {$[0.000]$} & [0.018] & {$[-0.002]$} \\
\hline \multirow[t]{3}{*}{ Mean Disciplinary Infraction Rate } & 0.238 & 0.589 & 0.196 \\
\hline & $(0.148)$ & $(0.547)$ & $(0.157)$ \\
\hline & [0.039] & [0.105] & [0.028] \\
\hline Observations & 1,281 & 795 & 646 \\
\hline
\end{tabular}




\begin{tabular}{|c|c|c|c|c|c|c|c|c|c|}
\hline & & \multicolumn{4}{|c|}{ A. Attendance Rate } & \multicolumn{4}{|c|}{ B. Disciplinary Infractions } \\
\hline & & \multicolumn{2}{|c|}{ i. Elementary } & \multicolumn{2}{|c|}{ ii. Middle/High } & \multicolumn{2}{|c|}{ i. Elementary } & \multicolumn{2}{|c|}{ ii. Middle/High } \\
\hline & & $(1)$ & $(2)$ & (3) & $(4)$ & $(5)$ & (6) & $(7)$ & $(8)$ \\
\hline \multirow[t]{2}{*}{ All } & Uniform Required & $\begin{array}{c}-0.018 \\
(0.040)\end{array}$ & $\begin{array}{l}-0.015 \\
(0.044)\end{array}$ & $\begin{array}{c}0.261^{*} \\
(0.143)\end{array}$ & $\begin{array}{c}0.422 * * * \\
(0.150)\end{array}$ & $\begin{array}{c}0.013 \\
(0.012)\end{array}$ & $\begin{array}{l}-0.003 \\
(0.008)\end{array}$ & $\begin{array}{c}0.021 \\
(0.056)\end{array}$ & $\begin{array}{c}0.018 \\
(0.059)\end{array}$ \\
\hline & Observations & 878,131 & 862,248 & $1,055,728$ & $1,027,308$ & 893,530 & 877,342 & $1,073,533$ & $1,044,250$ \\
\hline \multirow[t]{2}{*}{ Females } & Uniform Required & $\begin{array}{c}0.037 \\
(0.042)\end{array}$ & $\begin{array}{c}0.045 \\
(0.047)\end{array}$ & $\begin{array}{c}0.318 * * \\
(0.141)\end{array}$ & $\begin{array}{c}0.463^{* * *} \\
(0.166)\end{array}$ & $\begin{array}{c}0.002 \\
(0.006)\end{array}$ & $\begin{array}{l}-0.003 \\
(0.004)\end{array}$ & $\begin{array}{l}-0.013 \\
(0.042)\end{array}$ & $\begin{array}{c}0.016 \\
(0.046)\end{array}$ \\
\hline & Observations & 429,626 & 421,916 & 525,447 & 511,404 & 436,940 & 429,092 & 534,135 & 519,690 \\
\hline Males & Uniform Required & $\begin{array}{c}-0.064 \\
(0.044)\end{array}$ & $\begin{array}{l}-0.069 \\
(0.050)\end{array}$ & $\begin{array}{c}0.195 \\
(0.155)\end{array}$ & $\begin{array}{c}0.377 * * \\
(0.146)\end{array}$ & $\begin{array}{c}0.023 \\
(0.019)\end{array}$ & $\begin{array}{c}-0.004 \\
(0.012)\end{array}$ & $\begin{array}{c}0.053 \\
(0.073)\end{array}$ & $\begin{array}{c}0.020 \\
(0.074)\end{array}$ \\
\hline & Observations & 448,505 & 440,332 & 530,281 & 515,904 & 456,590 & 448,250 & 539,398 & 524,560 \\
\hline \multicolumn{2}{|c|}{ Student fixed-effects } & $\mathrm{X}$ & $\mathrm{X}$ & $\mathrm{X}$ & $\mathrm{X}$ & $\mathrm{X}$ & $X$ & $\mathrm{X}$ & $\mathrm{X}$ \\
\hline \multirow{2}{*}{\multicolumn{2}{|c|}{$\begin{array}{l}\text { School fixed-effects } \\
\text { Princinal fixed-effects }\end{array}$}} & $\mathrm{X}$ & $\mathrm{X}$ & $\mathrm{X}$ & $\mathrm{X}$ & $\mathrm{X}$ & $\mathrm{X}$ & $\mathrm{X}$ & $\mathrm{X}$ \\
\hline & & & $\mathrm{X}$ & & $\mathrm{X}$ & & $\mathrm{X}$ & & $\mathrm{X}$ \\
\hline
\end{tabular}

Standard errors clustered by school in parentheses. Elementary covers grades 1 - 5 and middle high covers grades 6 - 12. Each regression includes grade-by-year indicators, and the student's free-lunch, reduced-price lunch, or other economic disadvantage status. *, **, and *** denote statistical significance at the $10 \%$, $5 \%$, and $1 \%$ levels, respectively. Counts for the number of student, school and principal fixed-effects in each regression are provided in Online Appendix Table 2. 
Table 5 - Effect of Uniforms on In-School and Out-of-School Suspensions

\begin{tabular}{|c|c|c|c|c|c|c|c|c|c|}
\hline & & \multicolumn{4}{|c|}{ A. In-School Suspensions } & \multicolumn{4}{|c|}{ B. Out-of-School Suspensions } \\
\hline & & \multicolumn{2}{|c|}{ i. Elementary } & \multicolumn{2}{|c|}{ ii. Middle/High } & \multicolumn{2}{|c|}{ i. Elementary } & \multicolumn{2}{|c|}{ ii. Middle/High } \\
\hline & & $(1)$ & $(2)$ & $(3)$ & $(4)$ & $(5)$ & $(6)$ & $(7)$ & $(8)$ \\
\hline \multirow[t]{2}{*}{ All } & Uniform Required & $\begin{array}{c}0.005 \\
(0.006)\end{array}$ & $\begin{array}{l}-0.000 \\
(0.004)\end{array}$ & $\begin{array}{c}0.057 \\
(0.051)\end{array}$ & $\begin{array}{c}0.047 \\
(0.062)\end{array}$ & $\begin{array}{c}0.011 \\
(0.012)\end{array}$ & $\begin{array}{c}-0.002 \\
(0.006)\end{array}$ & $\begin{array}{l}-0.031 \\
(0.023)\end{array}$ & $\begin{array}{l}-0.018 \\
(0.018)\end{array}$ \\
\hline & Observations & 768,016 & 753,495 & 919,504 & 894,079 & 768,016 & 753,495 & 919,504 & 894,079 \\
\hline \multirow[t]{2}{*}{ Female } & Uniform Required & $\begin{array}{c}0.001 \\
(0.002)\end{array}$ & $\begin{array}{l}-0.000 \\
(0.002)\end{array}$ & $\begin{array}{c}0.021 \\
(0.041)\end{array}$ & $\begin{array}{c}0.041 \\
(0.049)\end{array}$ & $\begin{array}{c}0.002 \\
(0.006)\end{array}$ & $\begin{array}{c}-0.004 \\
(0.003)\end{array}$ & $\begin{array}{c}-0.031^{*} \\
(0.016)\end{array}$ & $\begin{array}{l}-0.017 \\
(0.014)\end{array}$ \\
\hline & Observations & 375,500 & 368,460 & 457,541 & 445,068 & 375,500 & 368,460 & 457,541 & 445,068 \\
\hline \multirow[t]{2}{*}{ Males } & Uniform Required & $\begin{array}{c}0.007 \\
(0.010)\end{array}$ & $\begin{array}{l}-0.000 \\
(0.006)\end{array}$ & $\begin{array}{c}0.093 \\
(0.064)\end{array}$ & $\begin{array}{c}0.054 \\
(0.075)\end{array}$ & $\begin{array}{c}0.019 \\
(0.018)\end{array}$ & $\begin{array}{l}-0.002 \\
(0.010)\end{array}$ & $\begin{array}{l}-0.033 \\
(0.032)\end{array}$ & $\begin{array}{l}-0.020 \\
(0.023)\end{array}$ \\
\hline & Observations & 392,516 & 385,035 & 461,963 & 449,011 & 392,516 & 385,035 & 461,963 & 449,011 \\
\hline \multirow{3}{*}{\multicolumn{2}{|c|}{$\begin{array}{l}\text { Student fixed-effects } \\
\text { School fixed-effects } \\
\text { Principal fixed-effects }\end{array}$}} & $\mathrm{X}$ & $\mathrm{X}$ & $\mathrm{X}$ & $\mathrm{X}$ & $\mathrm{X}$ & $X$ & $\mathrm{X}$ & $X$ \\
\hline & & $X$ & $X$ & $X$ & $X$ & $X$ & $X$ & $X$ & $X$ \\
\hline & & & $X$ & & $X$ & & $X$ & & $X$ \\
\hline
\end{tabular}

$\overline{\text { LUSD did not report disaggregated suspsension data in 1995-96 and 1996-97. Standard errors clustered by school in parentheses. Elementary covers grades } 1 \text { - }}$ 5. Middle/high covers grades 6 - 12. Each regression includes student fixed-effects, school fixed-effects, grade indicators, year indicators, interactions of grade and year indicators, and the student's free-lunch, reduced-price lunch, or other economic disadvantage status. *, **, and ${ }^{* * *}$ denote staistical significance at the $10 \%, 5 \%$, and $1 \%$ levels, respectively. 
Table 6: Effect of Uniforms Interacted with Student and School Ethnicity on Attendance and Discipline

\begin{tabular}{|c|c|c|c|c|c|c|}
\hline & \multicolumn{3}{|c|}{ A. Attendance } & \multicolumn{3}{|c|}{ B. Discipline } \\
\hline & $\begin{array}{l}\text { All } \\
(1)\end{array}$ & $\begin{array}{c}\text { Females } \\
(2)\end{array}$ & $\begin{array}{c}\text { Males } \\
\text { (3) }\end{array}$ & $\begin{array}{l}\text { All } \\
(4)\end{array}$ & $\begin{array}{c}\text { Females } \\
\text { (5) }\end{array}$ & $\begin{array}{c}\text { Males } \\
(6)\end{array}$ \\
\hline & \multicolumn{6}{|c|}{ i. Elementary } \\
\hline Uniform Required & $\begin{array}{c}-0.376^{* * *} \\
(0.092)\end{array}$ & $\begin{array}{c}-0.405^{* * *} \\
(0.110)\end{array}$ & $\begin{array}{c}-0.354^{* * *} \\
(0.101)\end{array}$ & $\begin{array}{l}-0.027 \\
(0.018)\end{array}$ & $\begin{array}{c}-0.016 * \\
(0.008)\end{array}$ & $\begin{array}{l}-0.036 \\
(0.027)\end{array}$ \\
\hline Uniform Required X Above-Median African-American X African-American & $\begin{array}{c}0.243^{* * *} \\
(0.085)\end{array}$ & $\begin{array}{c}0.140 \\
(0.112)\end{array}$ & $\begin{array}{c}0.345^{* * *} \\
(0.128)\end{array}$ & $\begin{array}{c}0.047 * * \\
(0.021)\end{array}$ & $\begin{array}{c}0.009 \\
(0.013)\end{array}$ & $\begin{array}{l}0.082 * * \\
(0.033)\end{array}$ \\
\hline Uniform Required X Above-Median Hispanic X Hispanic & $\begin{array}{c}0.037 \\
(0.076)\end{array}$ & $\begin{array}{c}0.039 \\
(0.083)\end{array}$ & $\begin{array}{c}0.023 \\
(0.101)\end{array}$ & $\begin{array}{l}-0.017 \\
(0.019)\end{array}$ & $\begin{array}{l}-0.011 \\
(0.012)\end{array}$ & $\begin{array}{l}-0.022 \\
(0.028)\end{array}$ \\
\hline Uniform Required X Above-Median African-American & $\begin{array}{l}-0.090 \\
(0.095)\end{array}$ & $\begin{array}{l}-0.116 \\
(0.102)\end{array}$ & $\begin{array}{l}-0.062 \\
(0.105)\end{array}$ & $\begin{array}{l}-0.010 \\
(0.021)\end{array}$ & $\begin{array}{c}-0.001 \\
(0.010)\end{array}$ & $\begin{array}{l}-0.019 \\
(0.033)\end{array}$ \\
\hline Uniform Required X Above-Median Hispanic & $\begin{array}{c}0.150 \\
(0.093)\end{array}$ & $\begin{array}{c}0.176 \\
(0.111)\end{array}$ & $\begin{array}{c}0.127 \\
(0.109)\end{array}$ & $\begin{array}{c}0.024 \\
(0.026)\end{array}$ & $\begin{array}{c}0.007 \\
(0.014)\end{array}$ & $\begin{array}{c}0.038 \\
(0.040)\end{array}$ \\
\hline Uniform Required X African-American & $\begin{array}{c}0.203^{* *} \\
(0.102)\end{array}$ & $\begin{array}{c}0.432 * * * \\
(0.126)\end{array}$ & $\begin{array}{c}-0.010 \\
(0.143)\end{array}$ & $\begin{array}{c}0.046^{* * *} \\
(0.017)\end{array}$ & $\begin{array}{c}0.034^{* * *} \\
(0.010)\end{array}$ & $\begin{array}{c}0.060 * * \\
(0.027)\end{array}$ \\
\hline Uniform Required X Hispanic & $\begin{array}{c}0.281^{* * * *} \\
(0.088)\end{array}$ & $\begin{array}{c}0.347 * * * \\
(0.106)\end{array}$ & $\begin{array}{c}0.242^{* *} \\
(0.108)\end{array}$ & $\begin{array}{c}0.023 \\
(0.015)\end{array}$ & $\begin{array}{c}0.011 \\
(0.008)\end{array}$ & $\begin{array}{c}0.033 \\
(0.024)\end{array}$ \\
\hline Above-Median African-American & $\begin{array}{l}-0.098 \\
(0.080)\end{array}$ & $\begin{array}{c}-0.005 \\
(0.106)\end{array}$ & $\begin{array}{c}-0.188^{* *} \\
(0.082)\end{array}$ & $\begin{array}{c}0.031 \\
(0.023)\end{array}$ & $\begin{array}{c}0.010 \\
(0.011)\end{array}$ & $\begin{array}{c}0.053 \\
(0.036)\end{array}$ \\
\hline Above-Median Hispanic & $\begin{array}{c}0.012 \\
(0.058)\end{array}$ & $\begin{array}{c}0.012 \\
(0.093)\end{array}$ & $\begin{array}{c}0.017 \\
(0.060)\end{array}$ & $\begin{array}{l}-0.028 \\
(0.044)\end{array}$ & $\begin{array}{l}-0.009 \\
(0.022)\end{array}$ & $\begin{array}{l}-0.044 \\
(0.065)\end{array}$ \\
\hline \multirow[t]{2}{*}{ Observations } & 878,131 & 429,626 & 448,505 & 893,530 & 436,940 & 456,590 \\
\hline & \multicolumn{6}{|c|}{ ii. Middle/High } \\
\hline Uniform Required & $\begin{array}{c}0.538 * * \\
(0.244)\end{array}$ & $\begin{array}{c}0.472 * \\
(0.244)\end{array}$ & $\begin{array}{c}0.624 * * \\
(0.267)\end{array}$ & $\begin{array}{c}-0.066 \\
(0.095)\end{array}$ & $\begin{array}{c}-0.067 \\
(0.070)\end{array}$ & $\begin{array}{l}-0.071 \\
(0.125)\end{array}$ \\
\hline Uniform Required X Above-Median African-American X African-American & $\begin{array}{c}0.595^{* * *} \\
(0.167)\end{array}$ & $\begin{array}{c}0.638 * * * \\
(0.198)\end{array}$ & $\begin{array}{c}0.565^{* * *} \\
(0.186)\end{array}$ & $\begin{array}{l}-0.047 \\
(0.048)\end{array}$ & $\begin{array}{l}-0.007 \\
(0.043)\end{array}$ & $\begin{array}{l}-0.081 \\
(0.063)\end{array}$ \\
\hline Uniform Required X Above-Median Hispanic X Hispanic & $\begin{array}{c}0.103 \\
(0.171)\end{array}$ & $\begin{array}{c}0.180 \\
(0.202)\end{array}$ & $\begin{array}{c}0.046 \\
(0.180)\end{array}$ & $\begin{array}{c}-0.014 \\
(0.045)\end{array}$ & $\begin{array}{c}-0.014 \\
(0.035)\end{array}$ & $\begin{array}{l}-0.020 \\
(0.071)\end{array}$ \\
\hline Uniform Required X Above-Median African-American & $\begin{array}{c}-0.426^{* *} \\
(0.212)\end{array}$ & $\begin{array}{l}-0.374 * \\
(0.205)\end{array}$ & $\begin{array}{c}-0.512^{* *} \\
(0.250)\end{array}$ & $\begin{array}{c}0.112 \\
(0.087)\end{array}$ & $\begin{array}{c}0.077 \\
(0.062)\end{array}$ & $\begin{array}{c}0.142 \\
(0.119)\end{array}$ \\
\hline Uniform Required X Above-Median Hispanic & $\begin{array}{c}-0.479 * * \\
(0.241)\end{array}$ & $\begin{array}{c}-0.518^{* *} \\
(0.250)\end{array}$ & $\begin{array}{c}-0.506^{*} \\
(0.266)\end{array}$ & $\begin{array}{c}0.144 \\
(0.098)\end{array}$ & $\begin{array}{c}0.116 \\
(0.071)\end{array}$ & $\begin{array}{c}0.176 \\
(0.132)\end{array}$ \\
\hline Uniform Required X African-American & $\begin{array}{c}-0.131 \\
(0.154)\end{array}$ & $\begin{array}{l}-0.122 \\
(0.155)\end{array}$ & $\begin{array}{l}-0.129 \\
(0.189)\end{array}$ & $\begin{array}{l}-0.029 \\
(0.073)\end{array}$ & $\begin{array}{l}-0.053 \\
(0.063)\end{array}$ & $\begin{array}{c}0.004 \\
(0.086)\end{array}$ \\
\hline Uniform Required X Hispanic & $\begin{array}{c}0.029 \\
(0.189)\end{array}$ & $\begin{array}{c}0.151 \\
(0.203)\end{array}$ & $\begin{array}{l}-0.082 \\
(0.207)\end{array}$ & $\begin{array}{l}-0.028 \\
(0.047)\end{array}$ & $\begin{array}{c}-0.034 \\
(0.038)\end{array}$ & $\begin{array}{l}-0.017 \\
(0.061)\end{array}$ \\
\hline Above-Median African-American & $\begin{array}{c}0.883^{* * *} \\
(0.210)\end{array}$ & $\begin{array}{c}0.891^{* * *} \\
(0.216)\end{array}$ & $\begin{array}{c}0.876^{* * *} \\
(0.224)\end{array}$ & $\begin{array}{c}-0.087 \\
(0.093)\end{array}$ & $\begin{array}{c}-0.069 \\
(0.071)\end{array}$ & $\begin{array}{l}-0.103 \\
(0.117)\end{array}$ \\
\hline Above-Median Hispanic & $\begin{array}{c}0.150 \\
(0.177)\end{array}$ & $\begin{array}{c}0.270 \\
(0.163)\end{array}$ & $\begin{array}{c}0.051 \\
(0.209)\end{array}$ & $\begin{array}{l}-0.112 \\
(0.121)\end{array}$ & $\begin{array}{l}-0.075 \\
(0.083)\end{array}$ & $\begin{array}{c}-0.149 \\
(0.159)\end{array}$ \\
\hline Observations & $1,055,728$ & 525,447 & 530,281 & $1,073,533$ & 534,135 & 539,398 \\
\hline
\end{tabular}

Standard errors clustered by school in parentheses. Each regression includes student and school fixed-effects along with grade indicators, year indicators, interactions of grade and year indicators, and the student's free-lunch, reduced-price lunch, or other economic disadvantage status. Elementary includes students in grades 1 - 5, while middle/high includes grades 6 12. *, **, and $* * *$ denote statistical significance at the $10 \%, 5 \%$, and $1 \%$ levels, respectively. 
Table 7: Effect of Uniforms on Achievement Gains

\begin{tabular}{|c|c|c|c|c|c|c|c|c|c|}
\hline & & \multicolumn{4}{|c|}{ A. Math } & \multicolumn{4}{|c|}{ B. Reading } \\
\hline & & \multicolumn{2}{|c|}{ i. Elementary } & \multicolumn{2}{|c|}{ ii. Middle/High } & \multicolumn{2}{|c|}{ i. Elementary } & \multicolumn{2}{|c|}{ ii. Middle/High } \\
\hline & & $(1)$ & $(2)$ & (3) & $(4)$ & (5) & (6) & $(7)$ & (8) \\
\hline \multirow[t]{2}{*}{ All } & Uniform Required & $\begin{array}{l}-0.020 \\
(0.029)\end{array}$ & $\begin{array}{l}-0.008 \\
(0.028)\end{array}$ & $\begin{array}{c}-0.024 \\
(0.023)\end{array}$ & $\begin{array}{c}-0.015 \\
(0.025)\end{array}$ & $\begin{array}{l}-0.015 \\
(0.022)\end{array}$ & $\begin{array}{l}-0.024 \\
(0.029)\end{array}$ & $\begin{array}{l}-0.014 \\
(0.011)\end{array}$ & $\begin{array}{l}-0.015 \\
(0.020)\end{array}$ \\
\hline & Observations & 239,272 & 233,891 & 420,165 & 412,259 & 238,759 & 233,413 & 420,058 & 412,114 \\
\hline \multirow[t]{2}{*}{ Females } & Uniform Required & $\begin{array}{c}-0.042 \\
(0.032)\end{array}$ & $\begin{array}{l}-0.027 \\
(0.035)\end{array}$ & $\begin{array}{l}-0.015 \\
(0.025)\end{array}$ & $\begin{array}{c}-0.004 \\
(0.028)\end{array}$ & $\begin{array}{c}-0.045 * \\
(0.024)\end{array}$ & $\begin{array}{c}-0.061^{* *} \\
(0.029)\end{array}$ & $\begin{array}{l}-0.008 \\
(0.012)\end{array}$ & $\begin{array}{l}-0.007 \\
(0.021)\end{array}$ \\
\hline & Observations & 117,551 & 114,878 & 211,909 & 207,919 & 117,338 & 114,682 & 211,967 & 207,975 \\
\hline \multirow[t]{4}{*}{ Males } & Uniform Required & $\begin{array}{c}-0.002 \\
(0.031)\end{array}$ & $\begin{array}{c}0.005 \\
(0.029)\end{array}$ & $\begin{array}{c}-0.033 \\
(0.021)\end{array}$ & $\begin{array}{l}-0.027 \\
(0.024)\end{array}$ & $\begin{array}{c}0.017 \\
(0.025)\end{array}$ & $\begin{array}{c}0.012 \\
(0.035)\end{array}$ & $\begin{array}{l}-0.020 \\
(0.013)\end{array}$ & $\begin{array}{l}-0.025 \\
(0.022)\end{array}$ \\
\hline & Observations & 121,721 & 119,013 & 208,256 & 204,340 & 121,421 & 118,731 & 208,091 & 204,139 \\
\hline & & \multicolumn{8}{|c|}{ C. Language } \\
\hline & Uniform Required & & & $\begin{array}{c}\text { i. Ele } \\
(9) \\
0.006 \\
(0.027)\end{array}$ & $\begin{array}{l}\text { ntary } \\
\qquad(10) \\
0.020 \\
(0.032)\end{array}$ & $\begin{array}{c}\text { ii. Mic } \\
(11) \\
0.005 \\
(0.013)\end{array}$ & $\begin{array}{c}\text { /High } \\
(12) \\
0.018 \\
(0.018)\end{array}$ & & \\
\hline All & Observations & & & 239,348 & 233,975 & 419,229 & 411,322 & & \\
\hline \multirow[t]{2}{*}{ Females } & Uniform Required & & & $\begin{array}{c}0.029 \\
(0.028)\end{array}$ & $\begin{array}{c}0.044 \\
(0.030)\end{array}$ & $\begin{array}{c}0.003 \\
(0.013)\end{array}$ & $\begin{array}{c}0.015 \\
(0.018)\end{array}$ & & \\
\hline & Observations & & & 117,619 & 114,943 & 211,552 & 207,550 & & \\
\hline Males & Uniform Required & & & $\begin{array}{l}-0.011 \\
(0.031)\end{array}$ & $\begin{array}{l}-0.000 \\
(0.037)\end{array}$ & $\begin{array}{c}0.006 \\
(0.015)\end{array}$ & $\begin{array}{c}0.021 \\
(0.021)\end{array}$ & & \\
\hline & Observations & & & 121,729 & 119,032 & 207,677 & 203,772 & & \\
\hline \multicolumn{2}{|c|}{ Student fixed-effects } & $\mathrm{X}$ & $\mathrm{X}$ & $\mathrm{X}$ & $X$ & $\mathrm{X}$ & $\mathrm{X}$ & $\mathrm{X}$ & $\mathrm{X}$ \\
\hline \multicolumn{2}{|c|}{ School fixed-effects } & $\mathrm{X}$ & $\mathrm{X}$ & $\mathrm{X}$ & $\mathrm{X}$ & $\mathrm{X}$ & $\mathrm{X}$ & $\mathrm{X}$ & $\mathrm{X}$ \\
\hline Principal & fixed-effects & & $\mathrm{X}$ & & $\mathrm{X}$ & & $\mathrm{X}$ & & $\mathrm{X}$ \\
\hline
\end{tabular}

$\overline{\text { Standard errors clustered by school in parentheses. Elementary covers grades } 1 \text { - } 5 \text { and middle high covers grades } 6 \text { - 12. Each regression includes grade-by-year }}$ indicators, and the student's free-lunch, reduced-price lunch, or other economic disadvantage status. *, **, and *** denote statistical significance at the $10 \%$, $5 \%$, and 1\% levels, respectively. Counts for the number of student, school and principal fixed-effects in each regression are provided in Online Appendix Table 2. 
Table 8: Effect of Unifroms on Leaving the District, Switching Schools, Grade Retention and Teacher Attrition

\begin{tabular}{|c|c|c|c|c|c|c|c|c|c|}
\hline & \multicolumn{4}{|c|}{ A. Switches Schools in LUSD } & \multicolumn{4}{|c|}{ B. Leaves LUSD } \\
\hline & & \multicolumn{2}{|c|}{ i. Elementary } & \multicolumn{2}{|c|}{ ii. Middle/High } & \multicolumn{2}{|c|}{ i. Elementary } & \multicolumn{2}{|c|}{ ii. Middle/High } \\
\hline & & $(1)$ & $(2)$ & $(3)$ & $(4)$ & (5) & $(6)$ & $(7)$ & $(8)$ \\
\hline \multirow[t]{2}{*}{ All } & Uniform Required & $\begin{array}{l}-0.002 \\
(0.007)\end{array}$ & $\begin{array}{l}-0.001 \\
(0.008)\end{array}$ & $\begin{array}{c}0.012 \\
(0.010)\end{array}$ & $\begin{array}{c}0.021 \\
(0.016)\end{array}$ & $\begin{array}{l}-0.004 \\
(0.003)\end{array}$ & $\begin{array}{c}0.002 \\
(0.003)\end{array}$ & $\begin{array}{l}-0.007 \\
(0.006)\end{array}$ & $\begin{array}{l}-0.011^{*} \\
(0.006)\end{array}$ \\
\hline & Observations & 700,988 & 688,578 & 757,637 & 738,315 & 700,988 & 688,578 & 757,637 & 738,315 \\
\hline \multirow[t]{2}{*}{ Females } & Uniform Required & $\begin{array}{l}-0.006 \\
(0.007)\end{array}$ & $\begin{array}{l}-0.004 \\
(0.008)\end{array}$ & $\begin{array}{c}0.010 \\
(0.009)\end{array}$ & $\begin{array}{c}0.020 \\
(0.015)\end{array}$ & $\begin{array}{l}-0.004 \\
(0.003)\end{array}$ & $\begin{array}{c}0.003 \\
(0.004)\end{array}$ & $\begin{array}{l}-0.010 \\
(0.006)\end{array}$ & $\begin{array}{l}-0.013^{*} \\
(0.007)\end{array}$ \\
\hline & Observations & 342,332 & 336,253 & 373,256 & 363,854 & 342,332 & 336,253 & 373,256 & 363,854 \\
\hline \multirow[t]{4}{*}{ Males } & Uniform Required & $\begin{array}{c}0.002 \\
(0.007)\end{array}$ & $\begin{array}{c}0.002 \\
(0.008)\end{array}$ & $\begin{array}{c}0.014 \\
(0.010)\end{array}$ & $\begin{array}{c}0.022 \\
(0.017)\end{array}$ & $\begin{array}{l}-0.003 \\
(0.004)\end{array}$ & $\begin{array}{c}0.003 \\
(0.004)\end{array}$ & $\begin{array}{l}-0.004 \\
(0.007)\end{array}$ & $\begin{array}{l}-0.010 \\
(0.006)\end{array}$ \\
\hline & Observations & 358,656 & 352,325 & 384,381 & 374,461 & 358,656 & 352,325 & 384,381 & 374,461 \\
\hline & & \multicolumn{4}{|c|}{ C. Grade Retention } & \multicolumn{4}{|c|}{$\begin{array}{c}\text { D. Teacher Attrition } \\
\text { (School-Year Level Regressions) }\end{array}$} \\
\hline & & \multicolumn{2}{|c|}{ i. Elementary } & \multicolumn{2}{|c|}{ ii. Middle/High } & \multicolumn{2}{|c|}{ i. Elementary } & \multicolumn{2}{|c|}{$\begin{array}{l}\text { ii. Middle/High } \\
(15) \\
\end{array}$} \\
\hline \multirow[t]{2}{*}{ All } & Uniform Required & $\begin{array}{l}-0.006^{*} \\
(0.003)\end{array}$ & $\begin{array}{c}0.001 \\
(0.004)\end{array}$ & $\begin{array}{l}-0.007 * \\
(0.004)\end{array}$ & $\begin{array}{l}-0.004 \\
(0.005)\end{array}$ & $\begin{array}{c}-0.046 * * * \\
(0.014)\end{array}$ & $\begin{array}{l}-0.036^{*} \\
(0.020)\end{array}$ & $\begin{array}{l}-0.019 \\
(0.015)\end{array}$ & $\begin{array}{l}-0.014 \\
(0.020)\end{array}$ \\
\hline & Observations & 594,032 & 583,832 & 885,866 & 864,795 & 1,213 & 1,176 & 811 & 737 \\
\hline \multirow[t]{2}{*}{ Females } & Uniform Required & $\begin{array}{l}-0.004 \\
(0.003)\end{array}$ & $\begin{array}{c}0.000 \\
(0.004)\end{array}$ & $\begin{array}{l}-0.006 \\
(0.004)\end{array}$ & $\begin{array}{l}-0.003 \\
(0.004)\end{array}$ & - & - & - & - \\
\hline & Observations & 290,486 & 285,535 & 442,560 & 432,087 & - & - & - & - \\
\hline Males & Uniform Required & $\begin{array}{c}-0.007 * \\
(0.004)\end{array}$ & $\begin{array}{c}0.001 \\
(0.004)\end{array}$ & $\begin{array}{c}-0.008^{*} \\
(0.004)\end{array}$ & $\begin{array}{c}-0.005 \\
(0.005)\end{array}$ & - & - & - & - \\
\hline & Observations & 303,546 & 298,297 & 443,306 & 432,708 & - & - & - & - \\
\hline \multirow{3}{*}{\multicolumn{2}{|c|}{$\begin{array}{l}\text { Student fixed-effects } \\
\text { School fixed-effects } \\
\text { Principal fixed-effects }\end{array}$}} & $\mathrm{X}$ & $\mathrm{X}$ & $\mathrm{X}$ & $\mathrm{X}$ & $\mathrm{X}$ & $\mathrm{X}$ & $\mathrm{X}$ & $\mathrm{X}$ \\
\hline & & $\mathrm{X}$ & $\mathrm{X}$ & $\mathrm{X}$ & $\mathrm{X}$ & $\mathrm{X}$ & $\mathrm{X}$ & $\mathrm{X}$ & $\mathrm{X}$ \\
\hline & & & $\mathrm{X}$ & & $\mathrm{X}$ & & $\mathrm{X}$ & & $\mathrm{X}$ \\
\hline
\end{tabular}

Standard errors clustered by school in parentheses. Switching, leaving, and grade retention: Elementary covers grades 1 - 5 and middle high covers grades 6 - 12. A student is identified as being retained if their grade in year $t$ is less than or equal to their grade in year $t-1$. Each regression includes grade-by-year indicators, and the student's free-lunch, reduced-price lunch, or other economic disadvantage status. *, **, and *** denote statistical significance at the $10 \%, 5 \%$, and $1 \%$ levels, respectively. Teacher attrition regressions: Elementary includes any school with enrollment in grades KG - 5. Middle/High includes any school with enrollment in grades 6-12. Some schools fall into both categories and hence there is overlap. Each regression includes year indicators and school-level share enrolled in each grade, female, free lunch, reduced-price lunch, other economic disadvantage, black, Hispanic, and white. Data on teacher attrition covers 1996-07 through 2004-05. Attrition is calculated by matching teacher names within a school across years. Counts for the number of student, school and principal fixedeffects in each regression are provided in Online Appendix Table 2. 